\title{
Canonical Notch Signaling Directs the Fate of Differentiating Neurocompetent Progenitors in the Mammalian Olfactory Epithelium
}

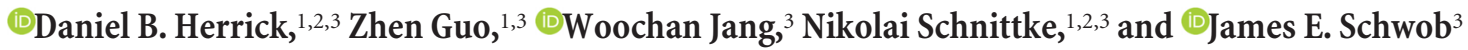 \\ ${ }^{1}$ Program in Cell, Molecular, and Developmental Biology, Sackler School of Graduate Biomedical Sciences, Tufts University, Boston Massachusetts 02111, \\ ${ }^{2} \mathrm{MD}-\mathrm{PhD}$ Program, and ${ }^{3}$ Department of Developmental, Molecular, and Chemical Biology, Tufts University School of Medicine, Boston Massachusetts \\ 02111
}

The adult olfactory epithelium (OE) has the remarkable capacity to regenerate fully both neurosensory and non-neuronal cell types after severe epithelial injury. Lifelong persistence of two stem cell populations supports $\mathrm{OE}$ regeneration when damaged: the horizontal basal cells (HBCs), dormant and held in reserve; and globose basal cells, a heterogeneous population most of which are actively dividing. Both populations regenerate all cell types of the $\mathrm{OE}$ after injury, but the mechanisms underlying neuronal versus non-neuronal lineage commitment after recruitment of the stem cell pools remains unknown. We used both retroviral transduction and mouse lines that permit conditional cell-specific genetic manipulation as well as the tracing of progeny to study the role of canonical Notch signaling in the determination of neuronal versus non-neuronal lineages in the regenerating adult OE. Excision of either Notch1 or Notch2 genes alone in HBCs did not alter progenitor fate during recovery from epithelial injury, whereas conditional knock-out of both Notch1 and Notch2 together, retroviral transduction of progenitors with a dominant-negative form of MAML (mastermind-like), or excision of the downstream cofactor RBPJ caused progeny to adopt a neuronal fate exclusively. Conversely, we show that overexpressing the Notch1intracellular domain (N1ICD) either genetically or by transduction blocks neuronal differentiation completely. However, N1ICD overexpression requires both alleles of the canonical cofactor RBPJ to specify downstream lineage. Together, our results suggest that canonical RBPJ-dependent Notch signaling through redundant Notch1 and Notch 2 receptors is both necessary and sufficient for determining neuronal versus non-neuronal differentiation in the regenerating adult $\mathrm{OE}$.

Key words: adult neurogenesis; canonical; chemical senses; Notch signaling; Notch1; RBPJ

Significance Statement

Despite the substantial reconstitution of the olfactory epithelium and its population of sensory neurons after injury, disruption and exhaustion of neurogenesis is a consequence of aging and a cause of olfactory dysfunction. Understanding the mechanisms underlying the generation of replacement neurons and non-neuronal cells is critical to any therapeutic strategy aimed at rebuilding a functional neuroepithelium. The results shown here demonstrate that canonical Notch signaling determines the balance between neurons and non-neuronal cells during restoration of the epithelium after injury. Moreover, the complexities of the multiple Notch pathways impinging on that decision are dissected in detail. Finally, RBPJ, the canonical Notch transcriptional cofactor, exhibits a heretofore unreported haploinsufficiency in setting the balance among the regenerating populations.

\section{Introduction}

Adult neural stem cells that have the capacity to participate in tissue regeneration after injury have been identified in the CNS and the olfactory epithelium (OE; Doetsch et al., 1999; Chen et al., 2004; Leung et al., 2007). However, the extent to which the OE can regenerate all epithelial cell types and reconstitute its preinjury structure throughout adult life is unparalleled compared with other parts of the mammalian nervous system (Graziadei and Monti Graziadei, 1979; Monti Graziadei and Monti Grazia-

Correspondence should be addressed to Dr. James E. Schwob, Department of Developmental, Molecular, and Chemical Biology, Tufts University School of Medicine,136 Harrison Avenue, Boston, MA 02111. E-mail: jim.schwob@tufts.edu.

D0I:10.1523/JNEUROSCI.0484-17.2018

Copyright $\odot 2018$ the authors $\quad 0270-6474 / 18 / 385022-16 \$ 15.00 / 0$ 
dei, 1979; Schwob et al., 1995, 2017; Schwob, 2002; Iwema et al., 2004).

Two stem cell populations, globose basal cells (GBCs) and horizontal basal cells (HBCs) play an integral role in maintaining OE tissue homeostasis throughout life and in regenerating the $\mathrm{OE}$ after severe tissue injury (Schwob et al., 2017). The GBC population is a morphologically uniform, but molecularly and functionally heterogeneous, population that sits at a slight remove from the basal lamina (Caggiano et al., 1994; Goldstein et al., 1998; Chen et al., 2004; Packard et al., 2011; Schwob et al., 2017). In contrast, HBCs are dormant, mitotically quiescent, reserve stem cells attached to the basal lamina deep to the GBCs and are rarely activated to multipotency in the absence of epithelial injury (Holbrook et al., 1995; Leung et al., 2007, Iwai et al., 2008). However, damage to the OE by administration of an olfactotoxin is capable of activating HBCs to multipotency through downregulation of p63, such that HBCs contribute to the regeneration of all epithelial cell types in the OE during tissue regeneration (Jang et al., 2003; Leung et al., 2007; Fletcher et al., 2011; Schnittke et al., 2015; Gadye et al., 2017). However, the mechanism(s) determining neuronal versus non-neuronal differentiation as HBCs and GBCs produce progeny in the regenerating adult $\mathrm{OE}$ has yet to be determined.

The Notch signaling pathway may play a role in cell-type specification in the developing OE (Carson et al., 2006; Rodriguez et al., 2008). The Notch signaling pathway is an evolutionarily conserved cell-cell signaling pathway that governs stem cell dynamics, progenitor fate choice, and cell proliferation. In canonical Notch signaling, Notch receptors (Notch1-4) are activated by Notch ligands (Delta-like1, 3, 4 and Jag1, 2) on neighboring cells at which point the cleaved intracellular domain of Notch (NICD) translocates to the nucleus, displaces repressor proteins and binds the cofactor RBPJ to initiate canonical gene transcription (Kopan and Ilagan, 2009; Artavanis-Tsakonas and Muskavitch, 2010). The most well characterized Notch target genes are of the Hes and Hey family transcription factors (Kopan and Ilagan, 2009). Notch signaling has been shown to play a role in determining progenitor fate in multiple adult tissues, notably in bone marrow (Han et al., 2002; Hozumi et al., 2003; de La Coste et al., 2005; Mercher et al., 2008), intestine (van Es et al., 2005; Riccio et al., 2008), and CNS (Ishibashi et al., 1994; Sakamoto et al., 2003; Imayoshi et al., 2010). Among the roles assigned to Notch signaling in the developing $\mathrm{OE}$ are the promotion of progenitor proliferation but inhibition of neurogenesis in the developing OE (Cau et al., 2002; Schwarting et al., 2007; Maier et al., 2011). Recently, we have demonstrated that Notch1 signaling helps to maintain HBC dormancy (Herrick et al., 2017). To date, however, the complexities of Notch signaling have not been fully elucidated.

Here, using in vivo retroviral transduction in rats and conditional gene knock-out/overexpression in mice, we demonstrate that canonical Notch signaling determines neuronal versus nonneuronal differentiation in the regenerating adult OE. Specifically, Notch 1 and Notch2 play redundant RBPJ-dependent roles in determining cell fate, but Notch2, and not Notch1, is required for the survival of Sus cells after their differentiation (Rodriguez et al., 2008). Interestingly, long-term N1ICD overexpression in HBCs results in increased cell proliferation and tumor formation. These results enable us to direct HBC cell fate both in vivo and in vitro in the setting of neuronal injury and tissue repair.

\section{Materials and Methods}

Animals and breeding. Wild-type F1 mice used for assessing immunohistochemical expression of Notch pathway components after MeBr lesion were bred from C57BL/6J and 129S1/Svlmj mice in house or ordered from the The Jackson Laboratory as needed (stock 101043). K5CreER ${ }^{\mathrm{T} 2}$ mice were described previously (Indra et al., 1999) and provided by $\mathrm{P}$. Chambon (University of Strasbourg, Strasbourg, France) via R. Reed (Johns Hopkins University School of Medicine, Baltimore, MD). The floxed Notch1 (Notch1 $1^{\text {tm2Rko }} /$ GridJ, stock 00695), floxed Notch2 (B6.129S-Notch2 $2^{\text {tm3Grid }} / \mathrm{J}$, stock 010525), and floxed-stop Notch1-ICD

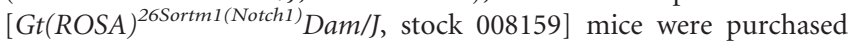
from The Jackson Laboratory and were bred in house (Murtaugh et al., 2003; Yang et al., 2004; McCright et al., 2006). The floxed RBPJ mouse, designated $R b p j^{\text {tm } 1 \text { Hon }}$ was provided by W. Cardoso (Columbia University Medical Center, New York, NY) and was described previously (Han et al., 2002). The Cre reporter mice R26R(TdTomato) [B6.CgGt(ROSA)26Sor ${ }^{\text {tm } 9(C A G-T d T o m a t o) H z e} / J$, stock 007909] were purchased from The Jackson Laboratory and described previously (Madisen et al., 2010). All animals were housed in a heat- and humidity-controlled AALAC-accredited vivarium operating under a $12 \mathrm{~h}$ light/dark cycle, and animals were maintained on an ad libitum rodent chow and water. Male Sprague-Dawley rats (Taconic) weighing 200-250 g were maintained on ad libitum food and water. The Committee for the Humane Use of Animals at Tufts University School of Medicine, where the animals were housed and the experiments conducted, approved all protocols using vertebrate animals.

$\mathrm{MeBr}$ lesions. Animals were passively exposed to $\mathrm{MeBr}$ gas for $8 \mathrm{~h}$ as described previously (Schwob et al., 1995; Chen et al., 2004). Twelveweek-old B6.129 F1 mice were exposed to $180 \mathrm{ppm} \mathrm{MeBr}$ in pure air, whereas all transgenic mouse lines were exposed to $175 \mathrm{ppm} \mathrm{MeBr}$ in pure air at 8 weeks of age. Rats weighing $300-325 \mathrm{~g}$ were exposed to 330 ppm MeBr.

Methimazole lesions. Methimazole was dissolved in PBS at a concentration of $10 \mathrm{mg} / \mathrm{ml}$ and administered to mice at 6 weeks of age at a dose of $50 \mathrm{mg} / \mathrm{kg}$ (i.p.). Mice are placed on heat pads for $1 \mathrm{~d}$ following administration, to ameliorate the anti-thyroid effects of the drug. Postinjection care is provided when necessary.

Drug preparation and administration. Tamoxifen (Sigma-Aldrich, T5648) was dissolved in sterile corn oil (USP grade) at $30 \mathrm{mg} / \mathrm{ml}$ at $37^{\circ} \mathrm{C}$ for $20 \mathrm{~min}$. This solution was injected intraperitoneally at $150-300$ $\mathrm{mg} / \mathrm{kg}$ as indicated. EdU (Invitrogen, A10044) was dissolved in sterile PBS at $5 \mathrm{mg} / \mathrm{ml}$ and injected subcutaneously under the back skin at 50 $\mathrm{mg} / \mathrm{kg} 2 \mathrm{~h}$ before kill.

Tissue processing. Animals were anesthetized using induction mixture and transcardially flushed with PBS and perfused with $40 \mathrm{ml}$ of $1 \%$ PLP ( $1 \%$ paraformaldehyde, $0.01 \mathrm{M}$ monobasic and dibasic phosphates, 90 mu lysine, $0.1 \mathrm{M}$ sodium periodate). After dissection of the $\mathrm{OE}$ turbinates and olfactory bulb, tissue was postfixed in $1 \%$ PLP for $1 \mathrm{~h}$ under vacuum. Tissue was washed with PBS and decalcified with saturated EDTA overnight. Tissue was cryoprotected in 30\% (w/v) sucrose in PBS overnight, embedded in optimal cutting temperature (OCT) compound (Miles), and frozen in liquid nitrogen. Coronal sections $(10 \mu \mathrm{m})$ were cut using a Leica cryostat, mounted on "Plus" slides (Fischer Scientific), and stored at $-20^{\circ} \mathrm{C}$ until used for immunohistochemical staining.

Replication-incompetent retroviral vector generation and concentration. The three plasmid constructs for the replication-incompetent MMLVderived retroviral vectors (RRV) (1)-expressing EGFP; (2) the constitutively active Notch1 intracellular domain (N1ICD) along with EGFP (both from Dr. Constance Cepko, Harvard University); and (3) the dominant-negative form of Mastermind-like DN-MAML and EGFP (a gift from Dr. Warren Pear, University of Pennsylvania) have been described previously (Maillard et al., 2004; Dang et al., 2006). Retrovirus (RV) was generated using standard calcium phosphate transfection method. Phoenix cells were split on the day before transfection to reach $50-70 \%$ confluence. DNA ( $10 \mu \mathrm{g} / 10 \mathrm{~cm}$ Petri dish) was incubated with 2 $\mathrm{M} \mathrm{CaCl}_{2}$ and $2 \times$ HBS buffer for $10 \mathrm{~min}$ on ice and then added dropwise to cells. Subsequently, chloroquine $(2 \mathrm{mg} / \mathrm{ml})$ was added to facilitate the entry of DNA. Cells were switched to fresh medium supplemented with $10 \%$ FBS at $16-18 \mathrm{~h}$ after transfection. Batches of RRV-contained supernatant was concentrated via a calcium phosphate precipitation method (Pham et al., 2001). Cells transfected with retroviral construct were switched to fresh, serum-free DMEM medium at $48 \mathrm{~h}$ after transfection 
and incubated overnight at $37^{\circ} \mathrm{C}$. Supernatant was collected and its $\mathrm{pH}$ was adjusted to 7.7 with $0.1 \mathrm{~N} \mathrm{NaOH}$. Supernatant was then filtered through $0.45 \mu \mathrm{m}$ filter, followed by the slow addition of $1 \mathrm{M} \mathrm{CaCl}_{2}$ to reach a final concentration of $60 \mathrm{~mm}$. The suspension was incubated at $37^{\circ} \mathrm{C}$ for $30 \mathrm{~min}$ to facilitate the formation of calcium phosphate precipitates, followed by centrifugation at $2050 \times g$ for $5 \mathrm{~min}$ at $4^{\circ} \mathrm{C}$. The precipitate was redissolved in $0.1 \mathrm{M}$ EDTA and dialyzed to remove EDTA. The typical titer of concentrated retrovirus was determined by the standard in vitro infection method on 3T3 cells. The typical titer of RV stocks used for intranasal infusion was in excess of $5 \times 10^{6}$ infectious particles per milliliters in an assay on 3T3 cells.

Nasal cavity infusion with $R V$. Host rats were exposed to $330 \mathrm{ppm}$ of $\mathrm{MeBr}$ gas for a period of $6 \mathrm{~h}$. One day after MeBr lesion, animals were anesthetized by intraperitoneal injection of induction mixture. After neck dissection and tracheotomy, $150 \mu \mathrm{l}$ of RV suspension, together with polybrene $(8 \mu \mathrm{g} / \mathrm{ml})$, was directly infused into the nasal cavity of the host rat using PE10 tube (BD Biosciences) inserted into $15 \mathrm{~mm}$ depth into the nasal cavity. Infused animals were kept at a surgical plane for 4 h by periodic supplemental injections of maintenance mixture and maintained with a supplemental heating source. Animals were allowed to survive for 2 weeks or 2 months before perfusion with fixative, the latter survival being used for long-term N1ICD-overexpression.

Antibody reagents and the identification of $O E$ cell types. The immunohistochemical classification and identification of the several olfactory epithelial cell types in this study are described in Table 1 . The primary antibodies used in this study to make cell type identifications are listed in Table 2. Information on the antibodies is derived from the manufacturers' description, the literature, and our own data.

Immunohistochemistry. The primary antibody dilutions and the details of their working conditions and detection are listed in Table 2. Before immunostaining, tissue sections were rinsed in PBS to remove OCT and subjected to antibody-specific pretreatments. The pretreatments include: heating in $0.01 \mathrm{M}$ citrate buffer, $\mathrm{pH} 6.0$, for $10 \mathrm{~min}$ in a commercial food steamer and/or incubation in 3\% hydrogen peroxide in $\mathrm{MeOH}$ for 5 min. Sections were blocked with $10 \%$ donkey serum $/ 5 \%$ nonfat dry milk/4\% BSA/0.1\% Triton X-100 in PBS and incubated for $1 \mathrm{~h}$ at room temperature in primary antibody. Subsequently, staining was visualized using the array of methods indicated in the table. Unless otherwise indicated, blue represents the nuclear counterstain 4',6-diamidino-2phenylindole.

EdU labeling. EdU (Invitrogen, A10044) was dissolved in sterile PBS at $5 \mathrm{mg} / \mathrm{ml}$ and injected subcutaneously under the back skin at $50 \mathrm{mg} / \mathrm{kg} 2 \mathrm{~h}$ before kill. For visualization of EdU incorporation, sections were permeabilized with $0.5 \%$ Triton X-100 in PBS, and treated with azide-594 containing Click-iT reaction mixture (Invitrogen) for $30 \mathrm{~min}$. After three washes in 3\% BSA in PBS, sections were steamed and stained for additional IHC markers.

Imaging and quantification. Stained tissue sections were imaged using a Zeiss 510 confocal microscope in multi-tracking mode. Image assembly was performed using Photoshop CS6 (Adobe). In all photographs, only balance and contrast were altered throughout the entire image using ImageJ.

Proliferation studies using EdU analysis were performed in the following manner. Mice were injected subcutaneously with $50 \mathrm{mg} / \mathrm{kg}$ EdU in PBS. EdU was detected using ClickIt-chemistry on prepared tissue sections (Invitrogen). EdU $(+) / \operatorname{TdTomato}(+)$ cells were counted by direct observation. In both mice and rats cell types were determined by direct observation using a Nikon $800 \mathrm{E}$ epifluorescence microscope. Following gene manipulation in mice, TdTomato $(+)$ cells that were negative for immunohistochemical staining with rabbit $\alpha$-PGP9.5 were classified as non-neuronal. TdTomato $(+)$ cells were counted and considered to be completely recombined at the loci of interest if the corresponding protein (Notch1, Notch2, or RBPJ) was absent by immunohistochemistry. Eight to 12 nonsequential sections were analyzed for TdTomato(+) regions. Data were pooled from three animals unless otherwise specified. Data were analyzed using Microsoft Excel software, with the appropriate statistical test as indicated in the text. In all graphs mean values and SEM are reported. Following retroviral infusion in rats, clones of labeled cells were analyzed with reference to the immunochemical markers listed above.
Clones were classified as having or lacking sustentacular cells and totaled for each of the treatment groups.

\section{Results}

Analysis of Notch receptors and targets in normal and injured olfactory epithelium

We first studied tissue-wide expression of components of the canonical Notch signaling pathway and its targets following acute injury to the OE of wild-type mice, which are confirmatory of previous findings examining recovery of the rat OE (Manglapus et al., 2004; Guo et al., 2010). These included changes in the pattern of immunohistochemical staining for the canonical Notch target, Hes1, and the two Notch receptors, Notch1 and Notch2 (Fig. 1). In the uninjured epithelium, in agreement with a previous microarray analysis of gene expression (Krolewski et al., 2013), Hes1 and Notch2 label both Sus cells, whose somata occupy the most apical zone of the epithelium (Fig. $1 A, A 1$, asterisks, $C$, single straight arrow; uninjured), and HBCs (Fig. $1 A, A 1, C$, double arrows; uninjured), whereas Notch1 labels HBCs (Fig. 1B, double arrows; uninjured) as well as a small population of GBCs (Fig. $1 B$, thick arrows; uninjured). In another study, we find that canonical Notch ligands Jag1 and Dll1 label Sus cells and HBCs, respectively (Herrick et al., 2017). We cannot detect any evidence of Notch1 or Notch2 receptors or Hes1 expression in neurons of the uninjured epithelium (Fig. 1), nor could we detect Notch3 or Notch4 staining in the OE either with or without injury (data not shown), which fits with the absence of significant expression of these receptors in microarray and RNAseq analyses of uninjured OE (Krolewski et al., 2013; Schnittke et al., 2015). In the acute phase of epithelial recovery at 2 and $3 \mathrm{~d}$ postlesion ( $\mathrm{dpl}$ ) some among the heterogeneous population of non-HBCs, identified as p63 $(-)$ cells that are displaced from the basal lamina, are $\operatorname{Notch} 1(+), \operatorname{Notch} 2(+)$, and/or Hes1(+) (Fig. 1 A, A1, thick arrows; at 2 and $3 \mathrm{dpl}$ ). Some of these are likely to be transitioning into GBCs to regenerate the neuronal population, but others may be differentiating into Sus cells directly (Manglapus et al., 2004). Between 4 and 7 dpl, the most heavily labeled Hes1 $(+)$ cells form an apical cell layer (Fig. $1 A, A 1$, straight thin arrows; at 4-7 dpl), and more lightly labeled Hes1(+) cells have reattached to the basal lamina, resumed p63 expression, and apparently are re-established as HBCs (Fig. $1 A, \mathrm{~A} 1$, double thin arrows; at $6 \mathrm{dpl}$ ). However, it is notable that many p63(+) cells, presumed HBCs, lack Hes1 staining (Fig. $1 A, A 1$, single thin arrows with asterisks; at $2-4 \mathrm{dpl}$ ), suggesting that they are not yet fully stabilized, given the contrast with the uninjured epithelium shown here (Fig. $1 A$; uninjured vs $2-4 \mathrm{dpl}$ ) and the role of Notch1 signaling in maintaining HBC quiescence (Herrick et al., 2017). Up through $4 \mathrm{dpl}$, Notch1 and Notch2 are scattered through the thickness of the OE, although some HBCs are distinctly Notch $1(+)$ (Fig. $1 B$, double arrows; at $4 \mathrm{dpl}$ ). However, by 5-6 dpl, Notch 1 is more established in the basal layer, whereas Notch2 is more prominent at the apex of the epithelium (Fig. $1 B$, double arrows vs $C$, single arrow; at 5 and $6 \mathrm{dpl}$ ). By 7 $\mathrm{dpl}$, the marker-based distinction between apical Sus cells and basal HBCs is more evident, such that Notch2 intensely stains Sus cells (Fig. 1C, single thin arrows; at 3-7 dpl) and faintly labels HBCs, whereas Notch1 now intensely labels the p63(+) HBCs (Fig. $1 B$, double arrows; at $7 \mathrm{dpl}$ ).

To examine more closely the transition of HBCs to Sus cells after injury, we assessed the pattern of CK14 and CK18 immunostaining after injury in combination with Hes1, the canonical downstream target of Notch signaling. At $1 \mathrm{dpl}$, Hes1 labels the vast majority of CK14 $(+)$ basal cells, some intensely, and many of 
Table 1. Cell types of the olfactory epithelium and the markers used in this study

\begin{tabular}{|c|c|c|c|c|c|c|c|c|c|c|c|c|}
\hline & p63 & CK5/CK14 & CD54 & Sox2 & Рax6 & NST & PGP9.5 & $0 M P$ & CK18 & Ezrin & REEP6 & Sus4 \\
\hline $\mathrm{HBCS}$ & ++ & ++ & ++ & + & + & - & - & - & - & - & - & - \\
\hline $\mathrm{GBCS}_{\text {up }}$ & - & - & - & + & + & - & - & - & - & - & - & - \\
\hline $\mathrm{GBC} \mathrm{s}_{\text {down }}$ & - & - & - & - & - & \pm & \pm & - & - & - & - & - \\
\hline OSNs $\mathrm{imm}_{\mathrm{imm}}$ & - & - & - & - & - & + & + & - & - & - & - & - \\
\hline $0 S N s_{\text {mat }}$ & - & - & - & - & - & \pm & + & ++ & - & - & - & - \\
\hline Sus $_{\text {imm }}$ & - & - & - & ++ & ++ & - & - & - & ++ & + & + & - \\
\hline Sus $_{\text {mat }}$ & - & - & - & ++ & ++ & - & - & - & ++ & + & + & + \\
\hline Duct/gland & - & - & - & - & ++ & - & - & - & + & \pm & + & + \\
\hline
\end{tabular}

++ Strongly positive, + positive, \pm weakly positive.

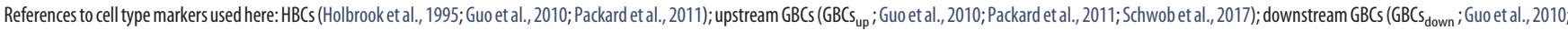

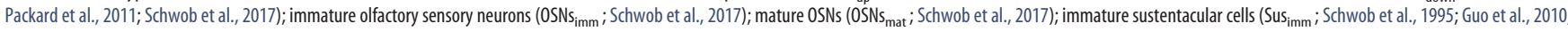
Krolewski et al., 2012); mature Sus cells (Sus mat ; Schwob et al., 1995; Huard et al., 1998; Guo et al., 2010; current paper, Fig. 4); Bowman's duct and gland cells (Schwob et al., 1995; Huard et al., 1998; current paper, Fig. 4).

Table 2. Antibodies used and their working conditions

\begin{tabular}{|c|c|c|c|}
\hline Primary antibody & Source/vendor & Immunogen & Protocol \\
\hline $\mathrm{Rb} \alpha$-activated Casp-3 & Cell Signaling Technology & $\begin{array}{l}\text { Large fragment of activated caspase-3 resulting from cleavage adjacent to } \\
\text { Asp175 }\end{array}$ & $(1: 100) \rightarrow$ fluor-DaRb \\
\hline Mo $\alpha$ - $\beta$ IV Tubulin & Sigma Aldrich & $\begin{array}{l}\text { Peptide corresponding to the } C \text {-terminal sequence of } \beta \text {-tubulin isotype IV, } \\
\text { conjugated to BSA }\end{array}$ & $(1: 100) \rightarrow$ fluor-DaMo \\
\hline Gt $\alpha$-CK14 & Santa Cruz Biotechnology & C-terminus of CK14 of human origin & $(1: 50) \rightarrow$ fluor-D $\alpha \mathrm{Gt}$ \\
\hline $\mathrm{Rb} \alpha-\mathrm{CK} 18$ & Abcam & C-terminus of human CK18 & $(1: 300) \rightarrow$ fluor-D $\alpha \mathrm{Rb}$ \\
\hline Gt $\alpha$-mouse CD54 & R\&D Systems & $\begin{array}{l}\text { Mouse myeloma cell line NSO-derived recombinant mouse ICAM-1/CD54, } \\
\text { GIn28-Asn485 }\end{array}$ & $(1: 50) \rightarrow$ fluor-D $\alpha \mathrm{Gt}$ \\
\hline $\operatorname{Rb} \alpha$-dsRed & Rockland Immunochemicals & Recombinant protein & $(1: 100) \rightarrow$ fluor-D $\alpha \mathrm{Rb}$ \\
\hline Chk $\alpha$-GFP & Aves Labs & Recombinant Protein & $(1: 1000) \rightarrow$ fluor-DaRb \\
\hline $\mathrm{Rb} \alpha$-Hes1 & Cell Signaling Technology & Recombinant protein specific to human Hes1 protein & $(1: 50) \rightarrow$ TSA $\rightarrow$ fluor-SA \\
\hline Gt $\alpha$-mCherry & SicGen & Purified recombinant peptide produced in Escherichia coli & $(1: 100) \rightarrow$ fluor-DaGt \\
\hline $\mathrm{Rb} \alpha$-Notch1 & Cell Signaling Technology (Danvers, MA) & Residues around Pro2438 of human Notch1 protein & $(1: 75) \rightarrow$ TSA $\rightarrow$ fluor-SA \\
\hline $\operatorname{Rb} \alpha$-Notch2 & Cell Signaling Technology & Residues around Ala2378 of human Notch2 protein & $(1: 150) \rightarrow$ TSA $\rightarrow$ fluor-SA \\
\hline Mo $\alpha$-0MP & Santa Cruz Biotechnology & Raised against aa 1-163 0MP of human origin & $(1: 100) \rightarrow$ fluor-D $\alpha M o$ \\
\hline Mo $\alpha$-p63 & Nordic BioSite & Recombinant fragment corresponding to human p63 aa 1-205 & $(1: 200) \rightarrow$ fluor-D $\alpha \mathrm{M}_{0}$ \\
\hline $\mathrm{Rb} \alpha$-PGP9.5 (UCHL1) & Protein Tech & Recombinant human UCHL1, aa 1-223 & $(1: 100) \rightarrow$ fluor-D $\alpha \mathrm{Rb}$ \\
\hline Rt $\alpha$-RBPJ & Cosmo Bio & Clone T6709 & $(1: 25) \rightarrow$ TSA $\rightarrow$ fluor-SA \\
\hline $\mathrm{Rb} \alpha-\mathrm{S} 0 \times 2$ & EMD Millipore & Recombinant GST fusion protein (Clone 6F1.2) & $(1: 100) \rightarrow$ TSA $\rightarrow$ fluor-SA \\
\hline $\operatorname{Rb} \alpha$-Sox 9 & EMD Millipore & $\begin{array}{l}\text { KLH-conjugated linear peptide corresponding to the C-terminal sequence of } \\
\text { human Sox } 9\end{array}$ & $(1: 500) \rightarrow$ fluor- $D \alpha R b$ \\
\hline Mo $\alpha$-Tuj1 & BioLegend & Microtubules derived from rat brain & $(1: 100) \rightarrow$ fluor-D $\alpha M_{0}$ \\
\hline
\end{tabular}

A variety of fluorophores (fluors) were used: green, AlexaFluor 488; red, AlexaFluor 594 (epifluorescence) or (y3 (confocal); blue, AMCA. Alexa-conjugated secondary Abs were used at 1:250. Cy3 conjugated reagents were used at 1:150 for directly conjugated secondary antibodies or 1:750 for TSA. AMCA was used at 1:100. Rb, Rabbit; Mo, mouse; Gt, goat; Chk, chicken; TSA, Tyramide Signal Amplification Kit from Perkin Elmer; b, biotinylated secondary antibody.

the same basal cells contain immuno-detectable CK18 as well (Fig. 2A-C, double arrows). At $2 \mathrm{dpl}$, CK14 and CK18 begin to label predominantly (but not exclusively) basally versus apically located cells, respectively (Fig. $2 D-F$ ). Some of the more apical CK18 $(+)$ cells are strongly Hes1 $(+)$, whereas others are not (Fig. $2 D-F$, arrows vs arrows with asterisks, respectively). It is worth noting that gland cells in the lamina propria are Hes1(-) (Fig. $2 D-F$, curved arrows), which absence is characteristic of the uninjured epithelium. The coexpression of CK14 and CK18, in contrast to their segregation in the normal epithelium, may be characteristic of cells that are now transitioning into duct/gland or Sus cells or alternatively, cells that are poised to go either back to $\mathrm{CK} 14^{+}$basal cells. OE cells maintained in culture can also exhibit a mixed cytokeratin phenotype (Jang et al., 2008), and bioinformatic analysis suggests that newly activated HBCs transition directly to Sus cells when p63 is conditionally excised or after epithelial lesion (Fletcher et al., 2017; Gadye et al., 2017).

\section{Manipulating Notch signaling determines cell fate after $\mathrm{MeBr}$ injury in rat $\mathrm{OE}$}

To investigate the role of the canonical Notch signaling pathway in determining cell fate after epithelial injury in rats, we infused replication-incompetent retroviral vectors encoding either GFPalone (pLIA-GFP), dominant-negative mastermind-like-GFP fusion protein (pLIA-dnMAML/GFP), Notch1 intracellular domain (pLIA-N1ICD-IRES-GFP) into the nasal cavity of MeBrexposed rats $1 \mathrm{dpl}$. Transduction of dividing progenitors spared by the lesion will lead to turning off or turning on canonical Notch signaling with the dnMAML construct or the N1ICD construct, respectively (Fig. 3A). Previous experiments that used intranasal infusion of retroviral vectors in the same manner demonstrated that the clusters of labeled cells that arise do so from a single infected progenitor cell, i.e., the clusters, which are widely dispersed, uniform in expression levels of the protein tag, and transduced by only one type of vector when a mixture of distinct vectors are infused, are clonal in origin (Huard et al., 1998). In the prior study of some 228 retrovirally transduced clones, $76 \%$ of the clones contained Sus cells and 30\% of the clones contained neurons. The vast majority of neuron-containing clones were mixed with respect to their composition; $93 \%$ of the neuron-containing clones also included Sus cells. Most of the clones that lacked neurons and Sus cells were comprised of duct and gland cells ( $21 \%$ of all clones). As expected on the basis of the prior results, infusion and transduction with the empty RV vector 

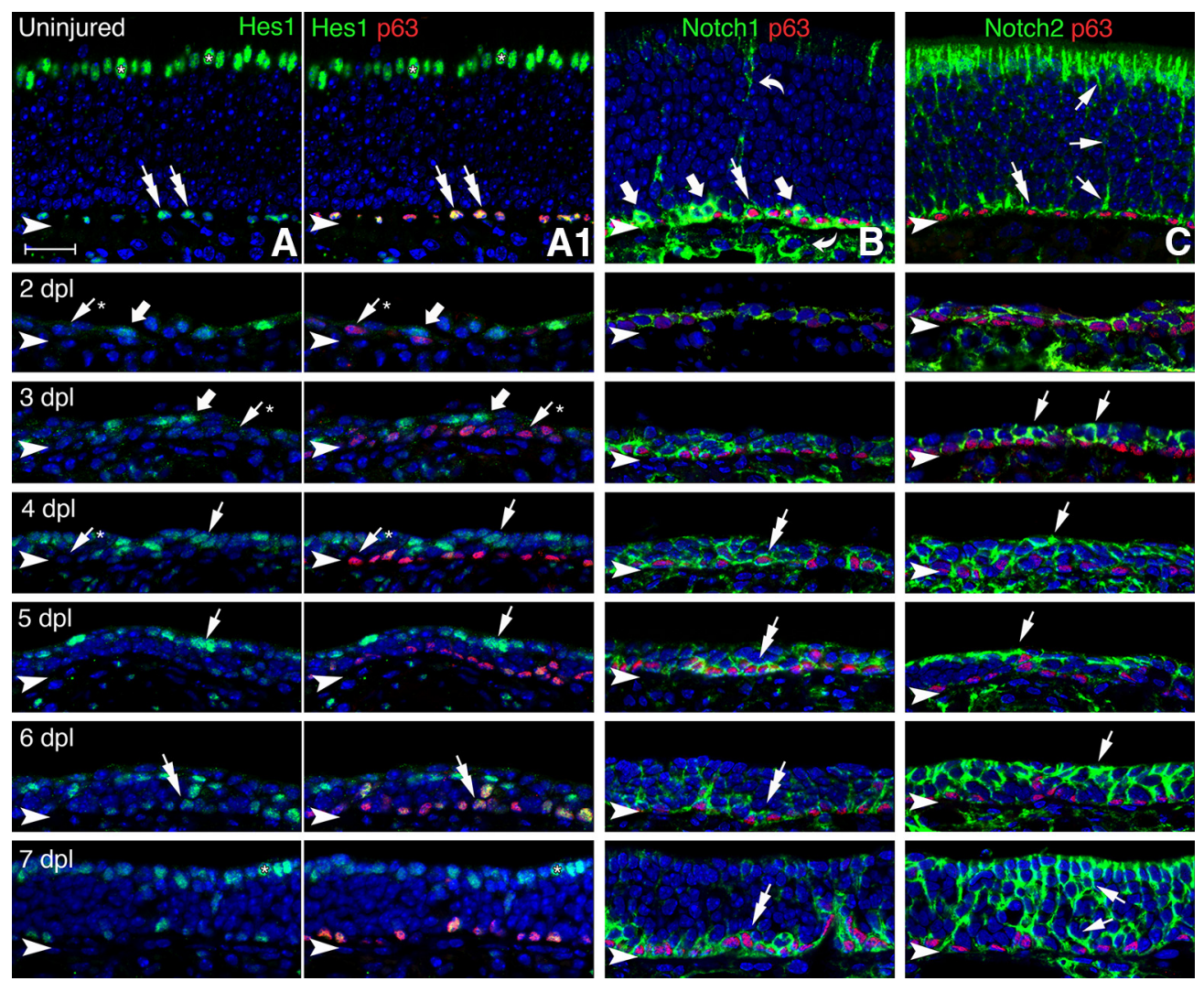

Figure 1. Immunohistochemical labeling demonstrates participation of Notch receptors and downstream targets during 0 E regeneration. In the uninjured mouse $0 \mathrm{E}$, Hes 1 and $\mathrm{p} 63 \mathrm{Co}$-label $\mathrm{HBCS}$ $[\boldsymbol{A}, \boldsymbol{A} \boldsymbol{1}$ (column), uninjured (row), double arrows], as does Notch1 and Notch2 ( $\boldsymbol{B}, \boldsymbol{C}$; uninjured, double arrows). In addition, Notch1 labels some GBCs ( $\boldsymbol{B}$, uninjured, thick arrows), but they do not express Hes1. Notch1 also labels gland cells deep to the basal lamina and cells lining the ducts that extend apically to the surface of the epithelium ( $\boldsymbol{B}$, uninjured, curved arrow). Notch2 labeling marks the foot process of the Sus cells (thin arrows), as well as the somata at the surface. The early response to MeBr lesion entails the downregulation of Hes 1 in the weakly p $63(+)) H B C s(\boldsymbol{A}, \boldsymbol{A} \mathbf{1}, 2 \mathrm{dpl}$, thin arrow with asterisk) and the expression of Hes 1 in cells situated apically to the $\mathrm{HBC}$, which may be either GBCs or cells transitioning directly into $\mathrm{Sus}$ cells ( $\boldsymbol{A}, \boldsymbol{A} \boldsymbol{A}, 2,3 \mathrm{dpl}$, thick arrow) (Manglapus et al., 2004; Guo et al., 2010). Hes1-labeled cells that are differentiating into fully-fledged Sus cells remain linked to the surface of the epithelium throughout the remainder of the first week after lesion $(\boldsymbol{A}, \boldsymbol{A} \mathbf{1}, 4-7 \mathrm{dpl}$, thin arrows), at the end of which they remain immature, but are demonstrably Sus cells $(\boldsymbol{A}, \boldsymbol{A} \boldsymbol{A}, 7 \mathrm{dpl}$, asterisk). Around this time, Hes 1 and p63 co-labeling of $\mathrm{HBC}$ also resumes $(\boldsymbol{A}, \boldsymbol{A} \mathbf{1}, 6 \mathrm{dpl}$, double arrows). Basal cell labeling with Notch1 remains the predominant staining pattern throughout the first week following injury (B, 2-7dpl) and the clear association of Notch1 with p63 in HBCs reappears by $4 \mathrm{dpl}$ ( $\boldsymbol{B}, 4-7 \mathrm{dpl}$, double arrows). In contrast, Notch2 labeling is concentrated at the surface from $3 \mathrm{dpl}$ onward ( $\boldsymbol{C}, 3-7 \mathrm{dpl}$, thin arrows), in parallel with Hes 1 labeling $(\boldsymbol{A}, \boldsymbol{A} \mathbf{1}, 3-6 \mathrm{dpl}$, thin arrow, $7 \mathrm{dpl}$, asterisks) and their differentiation to Sus cells. Arrowheads mark the basal lamina. Scale bar: (in $\boldsymbol{A}) \boldsymbol{A}-\boldsymbol{C}, 20 \mu \mathrm{m}$.
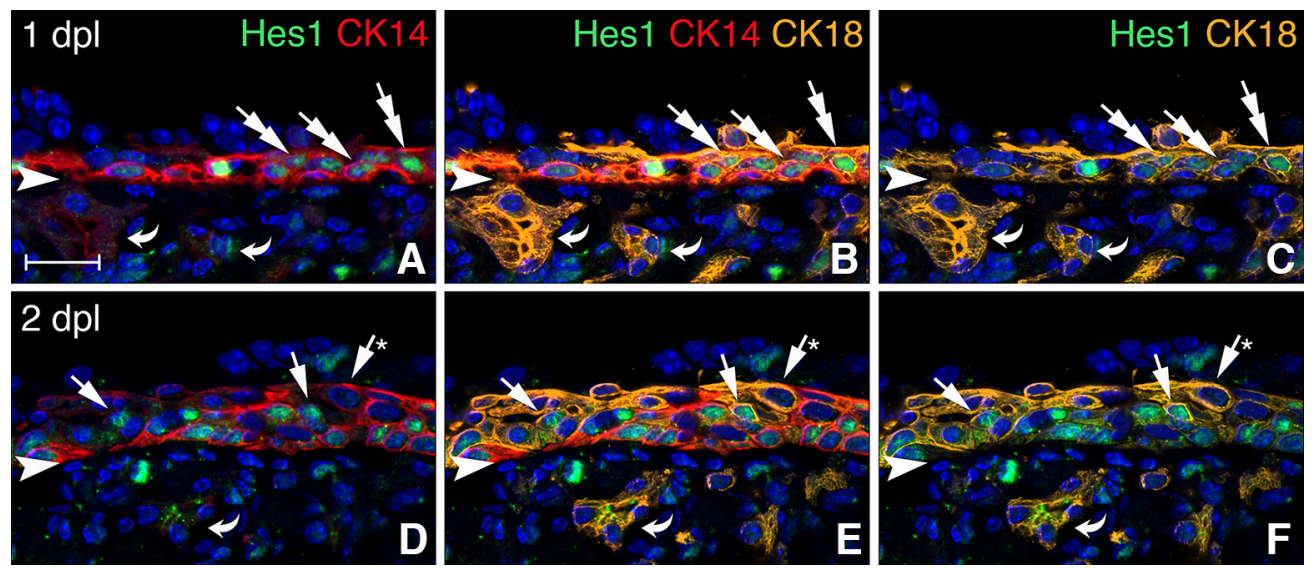

Figure 2. Displacement of Hes 1 apically is associated with the onset of CK18 expression. $\boldsymbol{A}-\boldsymbol{C}$, At $1 \mathrm{dpl}$ in mice, apically displaced Hes1-expressing cells coexpress both CK14 and CK18 (double arrows), whereas the duct cells express CK18 only (curved arrows). D-F, By 2 dpl, some of the Hes1(+) cells have lost CK14 positivity (single arrow). 0ther CK18(+) cells lack Hes1 (arrow with asterisk). Arrowheads mark the basal lamina. Scale bar: (in $\boldsymbol{A}) \boldsymbol{A}-\boldsymbol{F}, 20 \mu \mathrm{m}$.

(pLIA-GFP) resulted in a range of clone types at 2 weeks survival (Fig. $3 B, D, E$ ); some were complex and composed of neurons (thick arrows), Sus cells (curved arrows), and basal cells (straight arrows, the asterisk marks GBCs that nestle among the CD54(+)
HBCs but are distinct from them). In these, neurons were identified by their location in the middle of the epithelium and labeling with Tuj1 (thick arrows), whereas Sus cells were apical to the neurons and Sox $2(+)$, identifying them as Sus cells 


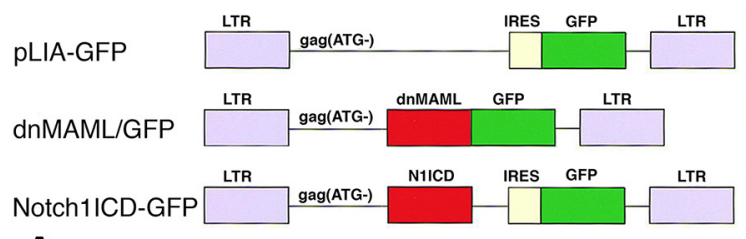

A
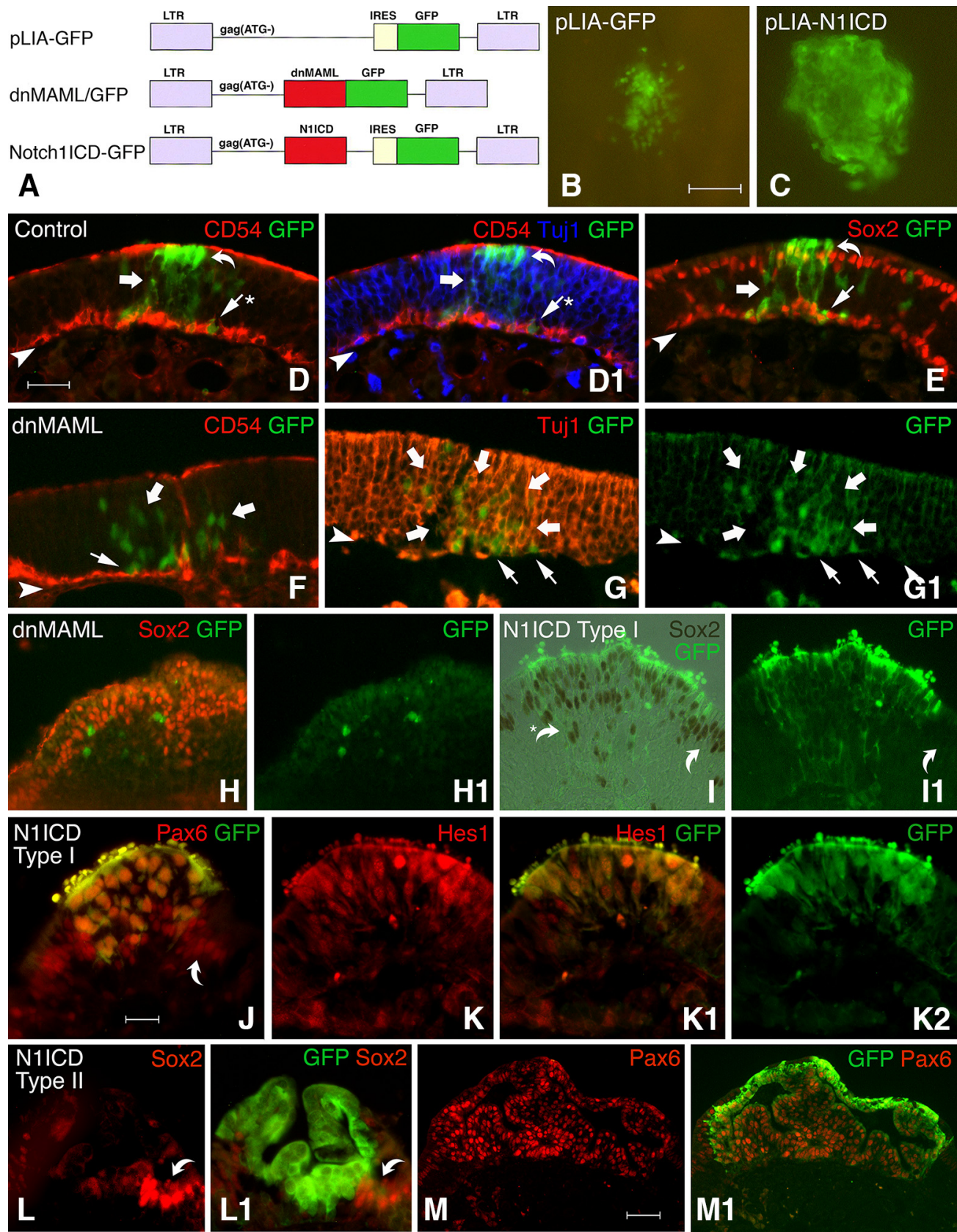

Figure 3. Retroviral transduction-mediated manipulation of the Notch pathway indicates that Notch signaling drives the differentiation of non-neuronal cells in the regenerating rat $0 \mathrm{E}$. $A$, Retroviral constructs, control (pLIA-GFP), repression of canonical Notch signaling via the dominant-negative form of Mastermind-like fused to GFP (dnMAML-GFP), and constitutively active Notch signaling via the Notch 1 intracellular domain (Notch1ICD-GFP), and (B, C) whole mounts of clones arising 2 weeks after retroviral transduction with control (pLIA-GFP) or constitutive Notch signaling (pLIA-N1ICD) vectors demonstrates the marked difference in effect; instead of the dispersion of the labeled cells seen with the GFP-only vector, N1ICD produces a large tight cluster of cells whose cell bodies are nearer the surface of the epithelium. $\mathbf{D}, \mathbf{D 1}, \boldsymbol{E}$, Two adjacent sections illustrating a clone generated by GFP-only transduction 2 weeks previously that contains a mixture of cell types: Sox2(+) Sus cells (curved arrows), TuJ1(+) olfactory neurons (thick arrows), Sox2(+) GBCs (thin arrows), and even CD54(+) HBCs (thin arrows with asterisk). In this and other panels, the designation " 1 " indicates different images of the same section. $\boldsymbol{F}-\boldsymbol{H} \mathbf{1}$, Three different clones generated following dnMAML transduction 2 weeks previously in which the vast majority of the cells are CD54(-), Sox2(-), Tuj1(+) neurons (thick arrows). Some GBCs are also seen (thin arrows). I-K2, Three different type I clones generated by N1ICD transduction 2 weeks previously. The transduced cells are Sox2 $(+)(\boldsymbol{I}, \boldsymbol{I 1}), \operatorname{Pax} 6(+)(\boldsymbol{J})$, and Hes1(+) $(\boldsymbol{K}-\boldsymbol{K} 2)$, even if found deeper in the epithelium (curved arrow with asterisk), as are non-transduced Sus cells adjacent to them (curved arrow). They form multiple layers of Sus-like cells at the surface of the epithelium. $L-M 1$, Two different type II clones generated by N1ICD transduction 2 weeks previously. The transduced cells are Pax6 $(+)$ $(\boldsymbol{M}, \mathbf{M 1})$ and Hes1 $(+)$ (data not shown) but do not express detectable Sox2 $(\boldsymbol{L}, \mathbf{L} \mathbf{1})$, in contrast to the Sus cells around them (curved arrow). The clones are convoluted and can form vesicles, which differentiates them from Sus cells or the Sus-like cells of the type I clones. Arrowheads mark the basal lamina. Scale bars: (in $\boldsymbol{B}) \boldsymbol{B}, \boldsymbol{C}, 50 \mu \mathrm{m}$; (in $\boldsymbol{D}) \boldsymbol{D}-\boldsymbol{H}, 25 \mu \mathrm{m}$; (in $\boldsymbol{J}) \boldsymbol{I}-\boldsymbol{L}, 15 \mu \mathrm{m}$; $\boldsymbol{M}, 50 \mu \mathrm{m}$.

(Fig. 3D,E, curved arrows). Other clones were composed of only neurons, only Sus cells, or a mixture of Sus, duct, and gland cells. Summing cellular composition across all of the empty vector-transduced clones, some $61.6 \%$ of the constituent cells were neurons. Particularly pertinent for the assessment of the role of Notch signaling in cell-type determination (described in the next section), 20 of 25 pLIA-GFP clones that we examined contained Sus cells (which comports well with the results of the previous study; Huard et al., 1998). For each clone type, the cells were indistinguishable in morphology and marker phenotype from the nontransduced cells of the surrounding epithelium. 
In contrast to complex or mixed clones observed with the control vector, transduction with the pLIA-dnMAML/GFP produced clones confined to the middle and lower regions of the $\mathrm{OE}$ that were composed of only Tuj-1(+) neurons (Fig. $3 F-H$, thick arrows) and GBCs (Fig. $3 F-H$, thin arrows) at the 2 week time point. It is noteworthy that the transduced cells were well integrated among, and closely resembled, the neurons and basal cells of the surrounding epithelium. The absence of Sox $2(+)$ Sus cells following dnMAML transduction was consistent and notable; all 40 of the clones generated across the two surviving animals infused with the dnMAML vector lacked Sus cells as defined by the usual morphological and immunolabeling criteria $\left(\chi^{2}=42.5\right.$, $p<0.001$ with Yates' correction; Fig. $3 F-H)$.

By comparison to the clones observed with either control or dnMAML vectors, the pLIA-N1ICD-transduced clones were markedly larger and did not resemble the composition of the epithelium in which they were embedded. On the basis of their cellular morphology, disposition within the tissue, and marker expression, the clones arising following N1ICD transduction and analyzed 2 weeks after transduction can be categorized into two dominant and easily distinguished clone types, which we term type I and type II, both of which were composed of non-neuronal epithelial cells. Of the 101 clones generated by pLIA-N1ICD transduction across three rats, 48 can be classified as type I and 49 as type II. The remaining four did not fall into either category, although they, too, lacked neurons, and were not analyzed in detail.

The cells comprising type I clones tend to merge fairly seamlessly with the surrounding OE (Fig. 3I-K). Type I clones were completely aneuronal. Instead, most of the transduced cells span the width of the OE and are roughly columnar in shape, like Sus cells (Fig. 3I-K). A smaller proportion of the cells are found deep to the layer of Sus cells and trail upward from the basal lamina (Fig. 3I, curved arrow with asterisk); they are marked by staining with a pan-keratin antibody (data not shown). They tend to form a tightly contiguous cluster that is easily recognizable when examining whole mounts (Fig. 3 C); that kind of clustering is also typical of Sus cell-only clones that are generated by transduction with a control vector (cf. Huard et al., 1998, their Fig. 9). The cells in the type I clones are heavily labeled with both anti-Sox 2 and anti-Pax6, as are the surrounding Sus cells (Fig. 3I, J, curved arrows). Although it is impossible to rule out the generation of an occasional pLIA-N1ICD-transduced neuron, the overwhelming majority of the cells in the type I clones are Sus cells.

In contrast, the cells in the type II clones form an irregular mass that pushes into, interrupts, and distorts the surrounding, non-transduced epithelium (Fig. $3 L, M$ ). The cells are fashioned into a highly convoluted epithelial monolayer, often arranged around a lumen. The cells of both clone types are Hes1(+) (type I, Fig. $3 K$; type II, data not shown), as would be expected in response to N1ICD expression. However, the cells of type II clones do not express Sox2 (Fig. 3L) unlike the surrounding Sus cells (Fig. $3 L$, curved arrows) and unlike the cells in the type I clones. The epithelial cells in the type II clones do express Pax6 (Fig. 3M) and Sox9 (data not shown); the molecular signature Sox $2(-) / \operatorname{Pax} 6(+) / \operatorname{Sox} 9(+)$ is characteristic of the cells comprising Bowman's ducts and glands (Guo et al., 2010; Lin et al., 2017). To further compare the cells of the type I and type II with Sus cells and duct/gland cells, we assessed labeling with other antibodies that mark Sus cells at various stages of their maturity (Fig. 4). Ezrin and REEP-6 are markers for both immature and mature Sus cells (Krolewski et al., 2012), whereas SUS4 is limited to more mature Sus cells (Goldstein and Schwob, 1996; Huard et al., 1998;
Chen et al., 2004; Krolewski et al., 2012; Fig. 4A-C). All three antibodies also stain duct/gland cells, but Ezrin does so weakly by comparison with SUS4 and REEP6 (Fig. 4, compare A-C).

After MeBr injury in the rat, the vast majority of the cells that are proliferating, exposed to the nasal cavity at the epithelial surface, and thus infectible are spared marker-defined GBCs and duct/gland cells (Huard et al., 1998). Based on differences in the morphology and molecular phenotype it is highly likely that the type I and type II clones arise from different cells of origin. By comparison with the outcomes of transplantation and lineage tracing experiments (Schwob et al., 1994; Goldstein et al., 1998; Huard et al., 1998; Chen et al., 2004, Schnittke et al., 2015; and see the next section), we favor the inference that GBCs that survive $\mathrm{MeBr}$ lesion give rise to type I clones following transduction with N1ICD, whereas residual duct/gland cells give rise to the type II clones; that inference is supported further by the finding that the transduced progeny in the type II clones are Sox2(-)/Pax6(+) like duct/gland cells (Guo et al., 2010).

Thus, the retroviral infusion results demonstrate that blocking Notch signaling forces neuronal differentiation while activating Notch signaling drives non-neuronal differentiation in whatever cell type has been transduced. However, with regard to the differences in outcome following pLIA-NICD transduction, and our interpretation that they reflect the identity of the specific cells infected by the virus, it is important to acknowledge that our inference can only be based on the composition of the clones that arise with this type of approach.

\section{Overexpression of N1ICD in HBCs drives Sus cell differentiation in the injured mouse $\mathrm{OE}$}

Because of the uncertainty in the cell of origin for the different types of clones observed with retroviral transduction, we also took a genetic approach to manipulate N1ICD expression in a cell-type-specific manner by taking advantage of the HBCspecific K5CreER ${ }^{\mathrm{T} 2}$ driver to excise the stop sequences inhibiting expression of Notch1-ICD (N1ICD) and of TdTomato in HBCs using K5Cre; R26R-fl(stop)N1ICD-GFP; fl(stop)TdTomato mice (Leung et al., 2007; Fletcher et al., 2011; Schnittke et al., 2015; Herrick et al., 2017). It is worth emphasizing that although both the N1ICD and TdTomato constructs are targeted mutations of the ROSA26 locus, equal efficiency of recombination cannot be assumed nor practically evaluated (Badea et al., 2009; Long and Rossi, 2009). Tamoxifen-induced recombination in HBCs and their expression of N1ICD had no discernable effect on the behavior of the TdTomato $(+)$ HBCs in the unlesioned OE, absent activation. The labeled HBCs remained flat cells, tightly adherent to the basal lamina, and part of the typical monolayer of HBCs, i.e., they were persistently dormant. Thus, we assessed the fate of HBCs and the cells they give rise to in a Notch-ON state after injury (Fig. 5A). Two weeks following administration of tamoxifen, the mice were lesioned by exposure to $\mathrm{MeBr}$ (Fig. 5B). Mice were perfused 4 weeks after injury at a time when the epithelium is substantially recovered in wild-type animals (Schwob et al., 1995; Chen et al., 2004; Holbrook et al., 2014; Schnittke et al., 2015). The vast majority of HBC-derived TdTomato(+) cells stain for the Sus cell markers Hes1, Sox2, and CK18, as well as Notch1, of course, and do not label with PGP9.5 (Fig. 5C-G). The N1ICD-expressing, HBC-derived cells closely resembled the type I clones generated by transduction with pLIA-NICD: columnar in shape and forming a compact cluster of cells in the apical layer of the epithelium. The TdTomato $(+)$ cells did not label with $\beta$ IV-tubulin, a marker of respiratory epithelium (Fig. $5 \mathrm{H}, \mathrm{I}$ ). In contrast, the majority of the cells observed after injury in 

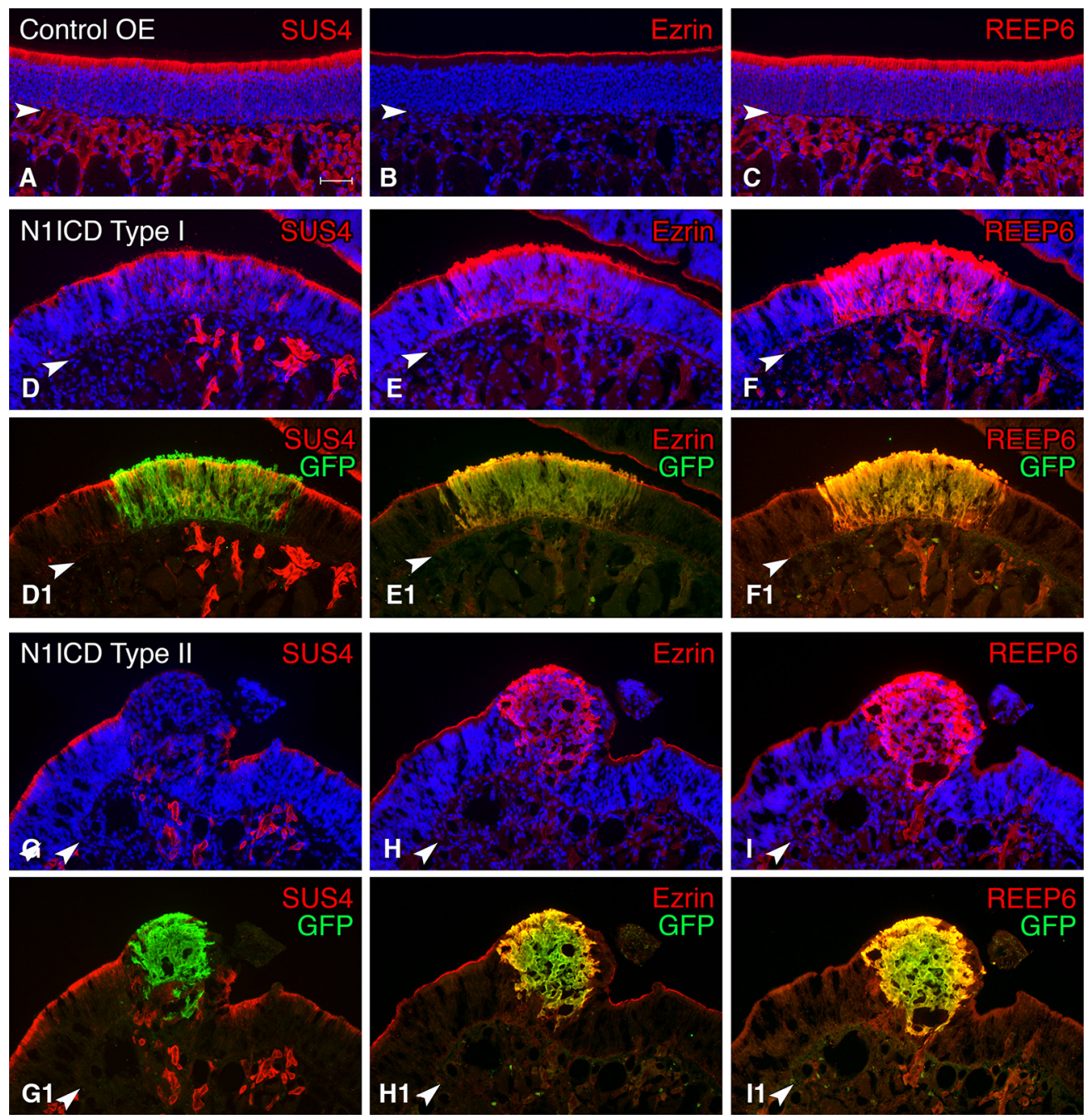

Figure 4. Type I N1ICD-transduced clones in rats resemble Sus cells, whereas type II clones are different. Staining with additional markers that label Sus and duct/gland cells reveals other differences between type I and type II clones. A-C, SUS4, Ezrin, and Reep6 all label Sus cells strongly in the uninjured OE. Duct/gland cells also label strongly with SUS4 and Reep6; Ezrin, not so much. D-F1, Type I clones are strongly positive for all three markers. G-I1, Type II clones lack SUS4 labeling, indicating that the cells are less well differentiated. The designation "1" indicates different images of the same section. Scale bar: (in $\boldsymbol{A}) \boldsymbol{A}-\boldsymbol{I 1}, 50 \mu \mathrm{m}$.

K5CreER ${ }^{T 2}$; fl(stop)TdTomato mice were marker-identified neurons (data not shown) in accordance with previous results (Leung et al., 2007; Fletcher et al., 2011; Schnittke et al., 2015; Herrick et al., 2017), and contrasts strongly with the scarcity of neurons in the N1ICD-expressing mice $(77.7 \pm 5.4 \%$ vs $0.4 \pm$ $0.7 \%$ neurons, respectively, $t=23.8 ; p<0.001, n=3)$. The few neurons observed in the K5Cre; fl(stop)N1ICD; fl(stop)TdTomato mice may reflect a disjunction between expression of TdTomato and the NIICD construct, even though they are both insertions into the ROSA26 locus.

\section{Notch1, Notch2, and combined Notch1/2 knock-outs shift cell fate after injury}

The foregoing data suggest that N1ICD expression in injuryactivated HBCs, or in GBCs, via retroviral transduction, apparently dictates Sus cell differentiation. The coexpression of Notch1 and Notch2 by HBCs raises the obvious question of whether Notch1 or Notch2 receptors or both are integral to, and necessary for, lineage specification after epithelial injury. The roles of Notch receptors in other tissues provide precedents for the involvement of either or both Notch1 and Notch 2 when both are expressed (Kumano et al., 2003; Cheng et al., 2007). Accordingly, we used several conditional knock-out lines to investigate the respective roles of Notch1, Notch2, and Notch $1 / 2$ deficiency in the setting of $\mathrm{OE}$ injury.

The several conditional knock-out lines that were used to study the effects of isolated loss of Notch receptors on cell fate after injury all use the $\mathrm{K} 5 \mathrm{CreER}{ }^{T 2}$ driver to accomplish recombination (Leung et al., 2007; Schnittke et al., 2015; Herrick et al., 2017; Fig. 6A). Mice of the appropriate genotype were treated with tamoxifen at 6 weeks of age, lesioned by injection with methimazole at 8 weeks, and killed 1 or 4 weeks after injury (Fig. 6B). With respect to Notch1, prior excision did not prevent the differentiation of Sus cells when assayed 1 week (data not shown) or 4 weeks after lesion (Fig. 6D,D1) compared with the wild-type control (Fig. 6C,C1). The earlier time point is soon after lineage commitment becomes evident (compare Fig. 1).

Similarly, the conditional excision of Notch2 did not prevent the formation of identifiable Sus cells, which were evident 1 week after lesion despite their lack of Notch2 labeling (Fig. $6 E$ ); our findings parallel and extend previous observations that constitutive knock-out of Notch2 does not prevent the formation of Sus cells during embryonic and neonatal development (Rodriguez et al., 2008). However, we do find enhanced activated Caspase 3 
A
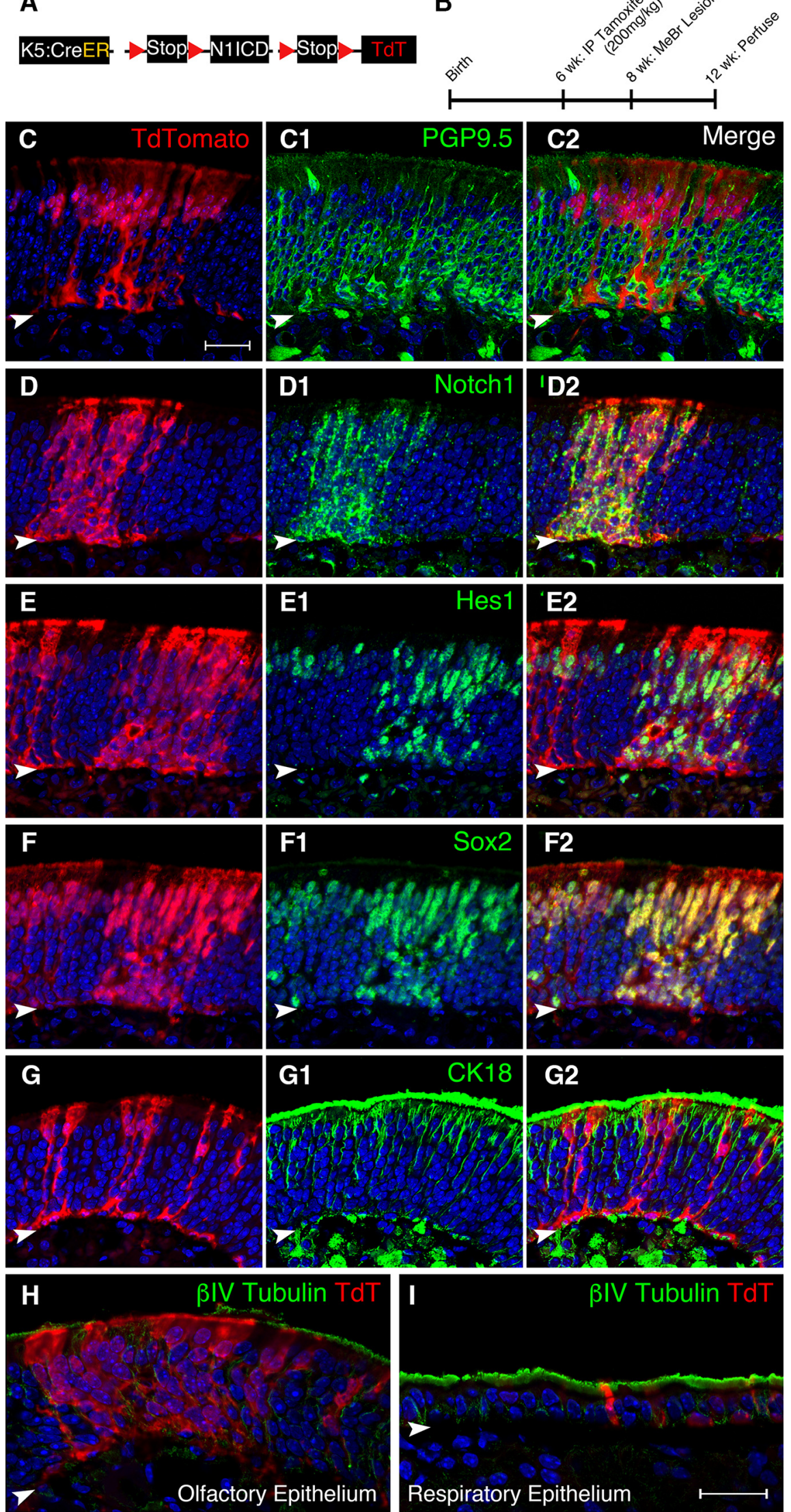

Figure 5. HBC-specific N1ICD overexpression drives the formation of non-neuronal, Sus-like cells in the regenerating mouse $0 \mathrm{E}$ $A$, Schematic of the mouse genotype used to assess the effect of N1ICD overexpression. The K5:CreER driver is HBC-specific. $B$, Experimental protocol. The $200 \mathrm{mg} / \mathrm{kg}$ dose of tamoxifen induces widespread but not universal recombination in $\mathrm{HBCs}$. staining in Sus cells at 1 week (Fig. $6 F$ ); for example, we found multiple fields that contained several Caspase $3(+)$ Sus cells in the Notch2 knock-out animals, which was never seen in the wild-type mice. Furthermore, HBC-derived, $\mathrm{TdT}(+)$ Sus cells were demonstrably scant at 4 weeks of survival (Fig. 6G). Indeed, those few $\mathrm{TdT}(+)$ Sus cells observed at 4 weeks survival in the Notch 2 conditional knock-out mice have demonstrable immunolabeling for Notch2, indicating that the knock-out was incomplete (Fig. 6G1,G2, arrows). The disappearance of the HBC-derived Notch2 $(-)$ Sus cells between 1 and 4 weeks after their generation also parallels the effect of developmental knock-out of Notch2 as referenced above (Rodriguez et al., 2008).

The preceding results suggest that either Notch1 or Notch 2 on its own is sufficient for the generation of Sus cells by HBCs. The consequences of doubleknock-out of Notch1 and Notch2 are decidedly different. In double-knock-out mice, HBCs gave rise to neurons almost exclusively at 1 week postlesion, which phenotype remained evident at 4 weeks postlesion (Fig. $6 H, H 1, I, I 1$ ); this is a marked shift away from non-neuronal fate compared with wild-type animals and the single gene knock-outs. Comparison of the effects of genotype on the percentage of neurons among the $\mathrm{HBC}$-derived progeny at 1 week after lesion demonstrates a statistically significant overall effect (Fig. 6J; one-way ANOVA, $F=68.47$, $p<0.001, n=3$ ). Also statistically significant were pairwise comparisons between Notch1/Notch2 double-knock-out versus Notch1 knock-out (Student's $t$ test, $t=$ 28.98, $p<0.001, n=3$ ), Notch1/Notch2 double-knock-out versus Notch2 knockout (Student's $t$ test, $t=9.25, p<0.001$, $n=3$ ), and Notch1/Notch2 doubleknock-out versus wild-type (Student's $t$ test, $t=22.79, p<0.001, n=3)$. Thus, both Notch1 and Notch2 must be eliminated in order for a strictly neuronal fate to be adopted by the descendants of

$\leftarrow$

Regeneration of the epithelium is nearing completion at 4 weeks after lesion. C-G2, Cells derived from N1ICDoverexpressing $\mathrm{HBCs}$ after MeBr lesion are PGP9.5(-) (C2), Notch1(+) (D2), Hes1(+) (E2), Sox2 (+) (F2), and CK18(+) (G2). Their appearance and marker-defined phenotype are Sus-like and closely resemble the cells of the type I clones induced by retroviral NICD transduction in rats (compare Figs. 3, 4). $\boldsymbol{H}, \boldsymbol{I}$, The HBC-derived cells are $\beta \mathrm{IV}$-tubulin $(-)(\boldsymbol{H})$, which is a marker of respiratory epithelium (I). The designations " 1 " and " 2 " indicate different images of the same section. Arrowheads mark the basal lamina. Scale bars: (in $\boldsymbol{C}) \boldsymbol{C} \boldsymbol{H}, 20 \mu \mathrm{m}$; , $50 \mu \mathrm{m}$. 
A

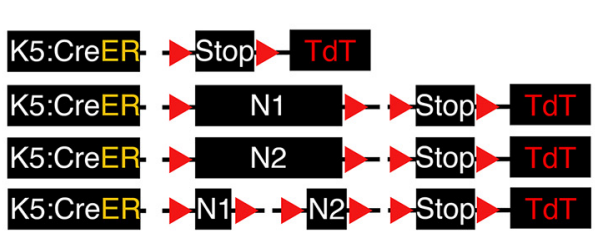

B
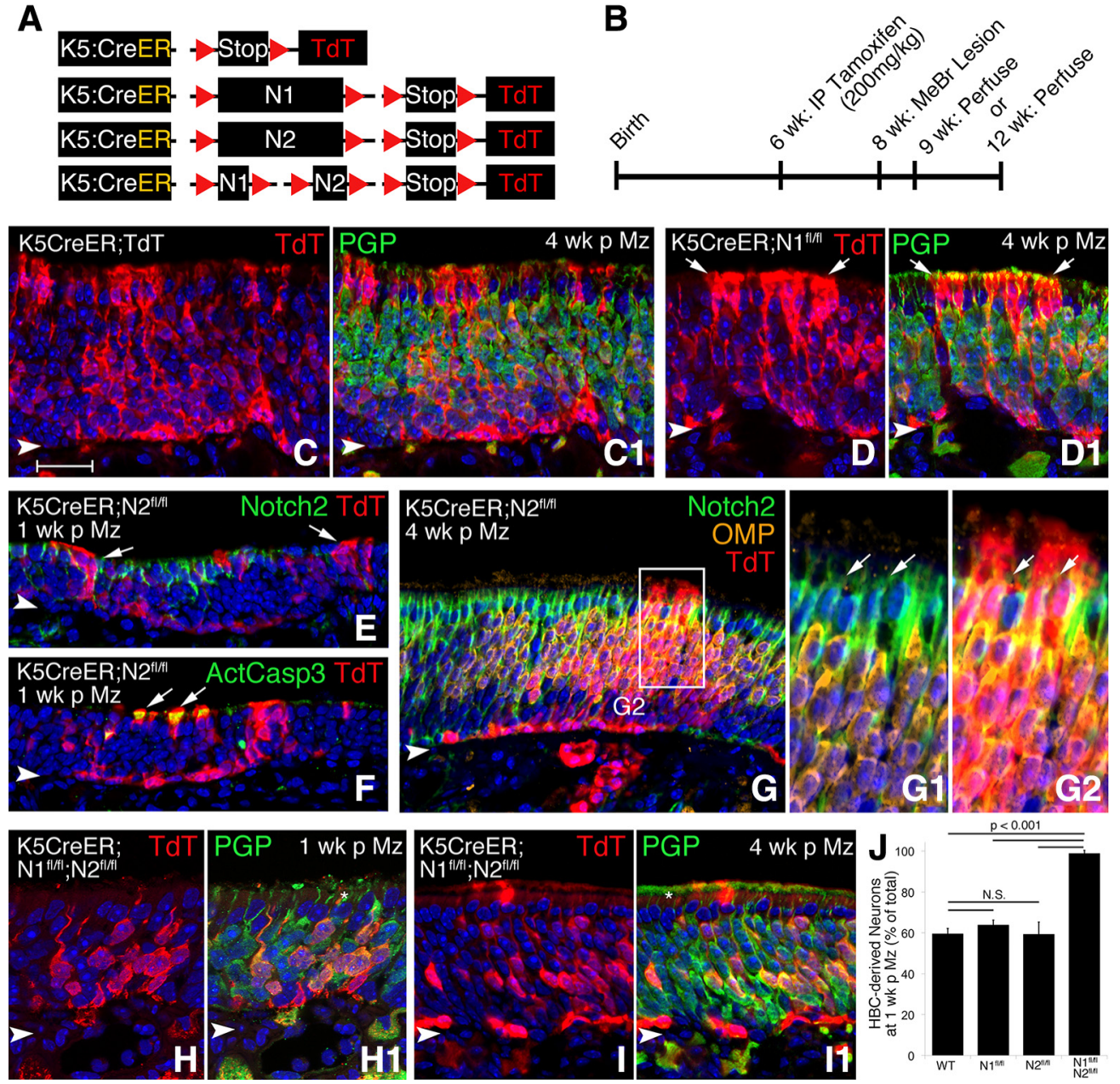

Figure 6. Conditional, HBC-specific deletion of both Notch 1 and Notch 2 is required to suppress the formation of Sus cells in the regenerating adult mouse $0 E$. $A$, Genotypes of the mouse strains used. $\boldsymbol{B}$, Experimental protocol. C, C1, HBC-derived clones that are wild-type for Notch1 and Notch2 genes (K5CreER;TdT) consist of both PGP( + ) neurons and Sus cells found superficial to the band of neurons. D, D1, Deletion of Notch1 in HBC does not alter differentiation of HBC-derived progeny, which includes Sus cells (thin arrow) and PGP( + ) neurons. $\boldsymbol{E}, \boldsymbol{F}, \mathrm{HBC}$-specific excision of Notch2. Deletion of Notch 2 does not prevent the formation of Sus cells at 1 week after lesion $(\boldsymbol{E}, \boldsymbol{F}$, arrows). However, the Sus cells are labeled for activated Caspase3 at that time point, suggesting that they are most likely dying ( $\boldsymbol{F}$, arrows). ( $\mathbf{G - G 2}$, HBC-specific excision of Notch2. In animals that survive for 4 weeks after methimazole injury, the epithelium lacks HBC-derived Sus cells, except in those few instances where HBC-derived Sus cells retain immunolabeling for Notch2 (G1, G2, arrows). $\boldsymbol{H}$-I1, Deletion of both Notch1 and Notch2 in HBCs prevents the formation of Sus cells at 1 week after lesion $(\boldsymbol{H}, \boldsymbol{H 1})$ and results in predominantly neuronal clones $(\boldsymbol{I}, \boldsymbol{I} \mathbf{I}) . \boldsymbol{J}$, Quantifying the percentage of HBC-derived neurons in mice of the specified genotypes at 1 week after lesion confirms the finding that both Notch1 and Notch2 have to be excised to prevent the formation of Sus cells. The designation "1" indicates different images of the same section. Arrowheads mark the basal lamina. Scale bar: (in $\boldsymbol{B}) \boldsymbol{A}-\boldsymbol{J}, 20 \mu \mathrm{m}$.

N1ICD-expressing, activated HBCs after injury; these data parallel the pro-neuronal effect of transduction with a dominantnegative construct of MAML (Fig. 3). It is likely that a failure to efficiently recombine at both alleles of both Notch1 and Notch2 explains why a few of the HBC progeny were able to adopt a non-neuronal fate.

\section{RBPJ mutation, which blocks canonical Notch signaling,} prevents Sus cell differentiation in response to N1ICD

As described in the section on retroviral transduction of the rat OE, retroviral transduction with dominant-negative MAML promotes neuronal differentiation and prevents the formation of Sus cells, suggesting that lineage specification driven by Notch signaling occurs via the canonical Notch pathway. Mutation by excision of the required canonical cofactor RBPJ provides an additional test of canonical involvement in Sus cell production subsequent to conditionally driven N1ICD expression in lesionactivated HBCs. Immunohistochemical staining of the $\mathrm{OE}$ with an anti-RBPJ antibody that binds to the DNA-binding domain
(DBD) marked all of the cells, and it intensely labeled immature neurons, i.e., those cells that are deep to the layer of $\mathrm{OMP}(+)$ neurons (Fig. 7D-D3; Herrick et al., 2017). The specificity of this antibody for the DBD has been established (Basch et al., 2011).

The role of RBPJ in driving Sus cell differentiation was assessed during recovery from $\mathrm{MeBr}$ injury using quadragenic strains of mice with the following genotypes: $K_{5 C r e E R}{ }^{T 2} ; R B P f^{f l+}$; fl(stop)N1ICD;fl(stop)TdTomato and K5CreER ${ }^{T 2} ; R B P J^{f l f l}$; fl(stop)N1ICD;fl(stop)TdTomato (Fig. 7A; Han et al., 2002). In the floxed RBJ mice, tamoxifen administration (Fig. $7 B$ ) leads to the excision of the DNA-binding domain of RBPJ of ostensibly one or both alleles, respectively. The expression of both TdTomato and N1ICD is also released by tamoxifen (Fig. 7A). In siblings that are wild-type at both RBPJ alleles $\left(\mathrm{K}_{\mathrm{CreER}}{ }^{T 2} ; \mathrm{RBPJ}^{+/+}\right.$; $f l$ (stop)N1ICD;fl(stop)TdTomato), the expression of N1ICD is sufficient after activation of the recombined HBCs to force nearuniversal Sus cell differentiation (Fig. 7C,F), see also (Fig. 5).

In both strains of RBPJ-targeted mice, i.e., those that were homozygous and those that were heterozygous for the floxed 
A

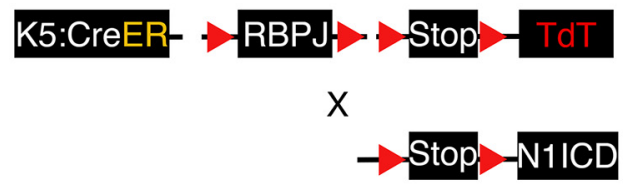

B
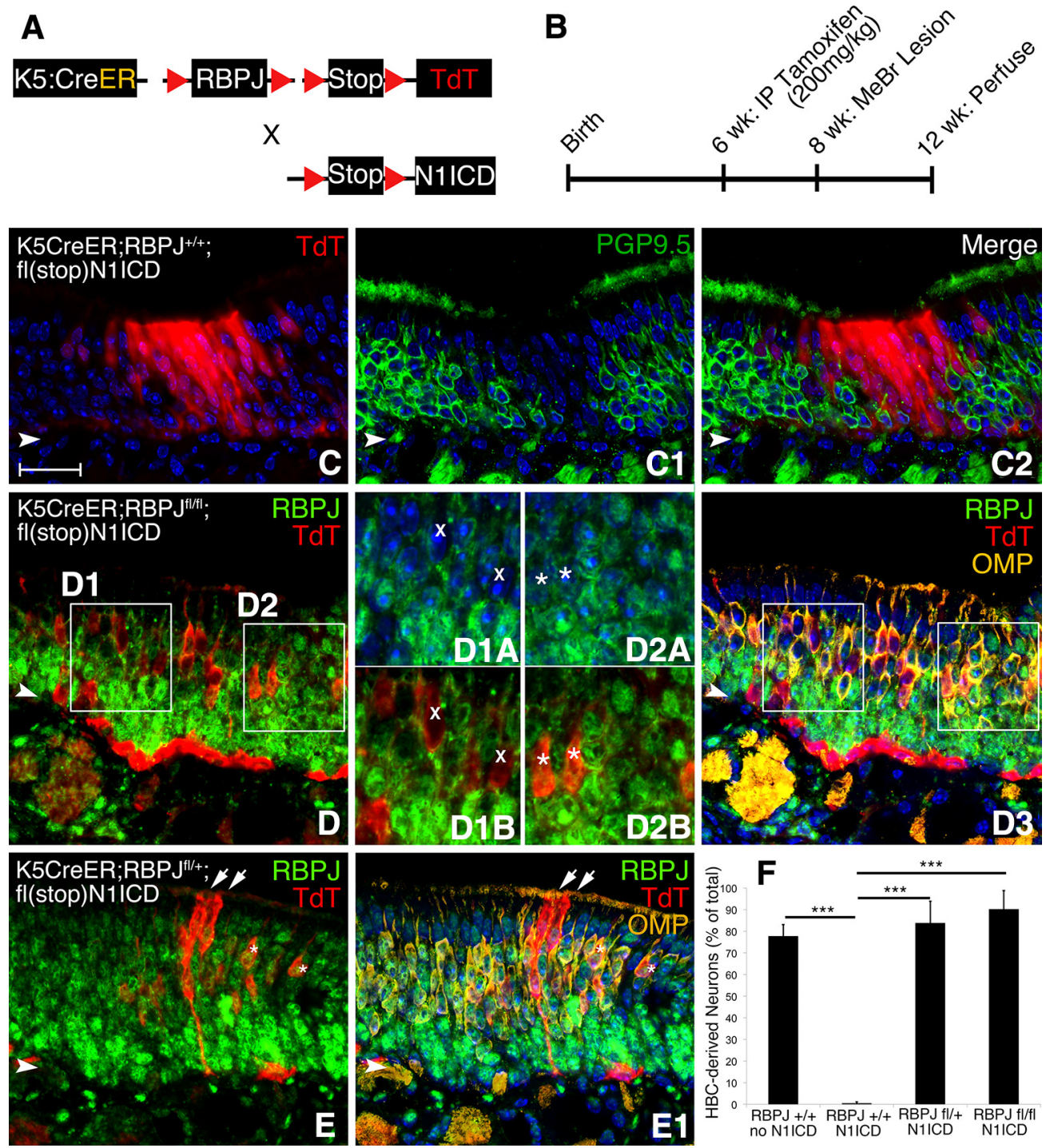

Figure 7. Conditional expression of N11CD in the mouse OE does not force the differentiation of Sus cells in the absence of RBPJ. $A$, Schematic of transgenic mice used in RBPJ/N1ICD lineage experiments. $\boldsymbol{B}$, Experimental protocol. $\mathbf{C}-\mathbf{C}$, In mice that are wild-type for RBPJ the descendants of N1ICD-expressing HBCs are exclusively Sus cells 4 weeks postinjury. $\boldsymbol{D}$-D3, In mice that are homozygous for the floxed RBPJ allele, conditional recombination shifts the descendants of HBCs to primarily a neuronal fate despite the exogenous expression of $N 1 I C D$; at least some mature to the point of OMP-expression. It is important to note that although some HBC-derived neurons demonstrably lack RBPJ-DNA-binding-domain staining (D1A, D1B, X), others retain RBPJ-DBD staining like the surrounding neurons (D2A, D2B, asterisks) suggesting that excision of a single copy may be sufficient to block Sus cell-like differentiation. $\boldsymbol{E}, \boldsymbol{E 1}$, In mice that are heterozygous for the floxed RBPJ allele, conditional recombination still shifts the descendants of HBCs to primarily a neuronal fate despite the exogenous expression of N1ICD (asterisks), confirming haploinsufficiency. Sus cells are seen more frequently when only one copy can be excised (arrows). $\boldsymbol{F}$, Quantification of neuronal versus non-neuronal progeny following HBC-specific recombination confirms the phenotype associated with both the homozygote and heterozygote RBPJ genotype. Arrowheads mark the basal lamina. Scale bar: (in C) $\mathbf{A}-\mathbf{C}, \mathbf{D} 3-\boldsymbol{F}, 20 \mu \mathrm{m}$.

RBPJ allele, tamoxifen-driven recombination in HBCs of the RBPJ gene and the other alleles led to the production of a very high percentage of neurons despite activation of N1ICD (Fig. $7 D-F)$; N1ICD ought to suppress neuronal differentiation and to lead to nothing but Sus cells (Fig. 7C). Indeed, neurons are generated to roughly the same extent in the heterozygotes and homozygotes (Fig. $7 F$ ) as in RBPJ-wild-type animals that do not express N1ICD (Fig. 7F). Statistical analysis demonstrated the overall significance of RBPJ mutation (one-way ANOVA, $F=$ $96.38, p<0.001$, the individual $n$ values for the 4 groups are listed with the pairwise comparisons which follow immediately) and significant pairwise effects [(1) N1ICD;RBPJ ${ }^{+/+}$vs N1ICD; $\mathrm{RBJ}^{+/ \mathrm{fl}}: t=-13.74, p<0.001, n=3,7$, respectively; (2) N1ICD; $\mathrm{RBPJ}^{+/+}$vs N1ICD;RBJ ${ }^{\mathrm{fl} / \mathrm{fl}}: t=-17.44, p<0.001, n=3,8$, respectively; (3) $\mathrm{RBPJ}^{+/+}$vs N1ICD;RBPJ ${ }^{+/+}: t=-23.88, p<$ $0.001, n=5,3$, respectively; Fig. $7 D-D 3, F]$. It is worth noting that many of the neurons that arise in the RBPJ mutant epithelium have matured to the point of OMP-positivity despite N1ICD expression (Fig. 7D3).

That the neuron-suppressive effect of N1ICD is blocked in the heterozygote was surprising, as RBPJ is not commonly described as haploinsufficient in mice (although RBJ heterozygous mutations demonstrate a variably penetrant phenotype in humans; Mašek and Andersson, 2017). Nonetheless, close analysis of the labeled cells in the epithelium of the RBPJ ${ }^{\mathrm{fl} / \mathrm{fl}}$ mice also supports the finding of haploinsufficiency in that a goodly proportion of the TdTomato $(+)$ neurons retained some RBPJ-DBD labeling (Fig. 7D2A,D2B, asterisks). Likewise, neurons that stain for RBPJ are also prevalent in the RBPJ+/fl mice (Fig. $7 E, E 1$, asterisks). The presence of RBPJ-DBD staining in neurons that have undergone recombination suggests that they retain one intact copy of the gene. Other HBC-derived OSNs in the homozygous mice 
A

B

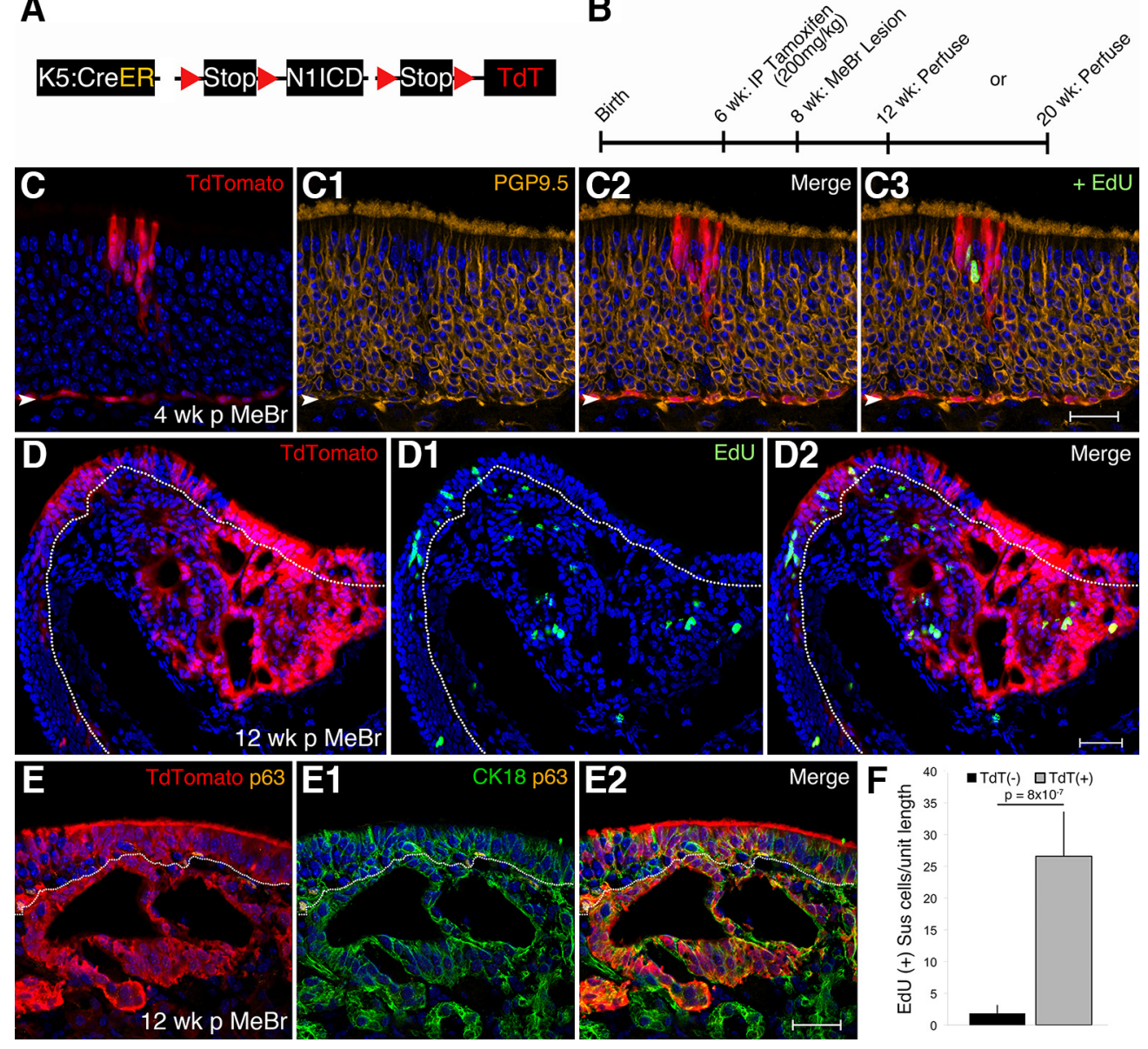

Figure 8. Long-term constitutive N1ICD expression leads to the formation of tumors in the mouse following activation of HBCs by MeBr lesion. $A$, Genotype of mice used to assess the long-term role of N1ICD in Sus cell differentiation. B, Experimental protocol. C-C3,4 weeks after MeBr injury, the N1ICD/TdT-expressing cells are Sus-like, but present in multiple layers and highly proliferative by comparison with surrounding Sus cells (C3); not that none of the surrounding Sus cells have incorporated EdU, whereas a significant fraction of the N1ICD-expressors do. Arrowheads designate the basal lamina. D-E2, At 12 weeks postinjury, some of the progeny of N1ICD-expressing HBCs retain a Sus-like phenotype in that they are confined to epithelium, e.g., the ones located at the bend of the epithelium in $\boldsymbol{D}$, although they are dividing at an increased rate (D1; EdU). However, other cells have grown into disorganized cell masses that occupy the full thickness of the epithelium, displace the $\mathbf{p 6 3}(+) \mathrm{HBC}$, and breach the basal lamina to extend deeply into the lamina propria. (D-D2, E-E2). They, too, show a high rate of proliferation (D1, D2; EdU), but they maintain expression of CK18 (E1, E2). Dashed white lines mark the basal lamina. F, Quantification of proliferation of wild-type mice [TDT(-)] versus N1ICD-expressing [TdT(+)] Sus cells. Scale bar: C3, 20 $\mu \mathrm{m} ; \mathbf{D 2}, 200 \mu \mathrm{m} ; E 2,100 \mu \mathrm{m}$.

lacked detectable staining with the anti-RBPJ-DBD antibody (Fig. 7D1A,D1B, "X's"). The presence of occasional RBPJ$\operatorname{DBD}(+)$ Sus cells in the RBPJ ${ }^{+/ f l}$ mice (Fig. 7 E, E1, arrows) may reflect a failure of recombination at the floxed allele, but that cannot be ascertained at present.

Thus, despite giving mice a very high dose of tamoxifen in an attempt to achieve complete recombination at both RBPJ alleles, it appears that recombination was still incomplete in many instances. Both the results in the heterozygous mice and in the incompletely recombined homozygous mice suggesting that RBPJ is, indeed, haploinsufficient. Clearly the data demonstrate that RBPJ and thus canonical Notch signaling are required for N1ICD to drive lineage commitment.

\section{Long-term effects of N1ICD overexpression}

Studies in other tissues have demonstrated that dysregulated Notch signaling can be either oncogenic (Ellisen et al., 1991; Zagouras et al., 1995; Pear et al., 1996; Weijzen et al., 2002) or tumor-suppressing (Talora et al., 2002; Nicolas et al., 2003; Radtke and Raj, 2003). To determine the consequences of a prolonged Notch-ON state in the OE, K5CreER ${ }^{T 2}$; fl(stop)N1ICD; fl(stop)TdTomato mice were treated with tamoxifen, exposed to
MeBr 2 weeks later and then killed either 4 or 12 weeks after injury (Fig. $7 A, B$ ). At the shorter time-point, the TdTomatolabeled cells were exclusively non-neuronal, as expected (Fig. $8 C$ C3). Notably, many of the TdTomato-positive Sus cells were also labeled by the incorporation of EdU, a marker of proliferation (Fig. 8C3). At 12 weeks after injury, some TdTomatopositive clusters were extremely large, occupying a broad swathe of the OE, breaching the basal lamina and extending into the lamina propria (Fig. $8 D-D 2$ ). Within the lamina propria the tdTomato-labeled cells often formed complex cystic structures (Fig. 8D-E2). EdU incorporation by the TdTomato $(+)$ cells remained prevalent at this time [Fig. 8D1,D2,F; Edu incorporation in $\mathrm{TdT}(-)$ vs $\mathrm{TdT}(+)$ cells, paired $t$ test, $p<0.001, t=-9.27, n=7]$. The maintained proliferation is markedly different from the usual mitotic quiescence of Sus cells at this time point in the recovery of the tissue after $\mathrm{MeBr}$ lesion (in the absence of exogenous N1ICD expression; Schwob et al., 1995). The large size of the labeled cell clusters may reflect this enhanced proliferation of TdTomato $(+)$ cells in the $f l$ (stop)N1ICD mice. In clones that invaded lamina propria, we find that the basal HBC layer of the OE had generally 

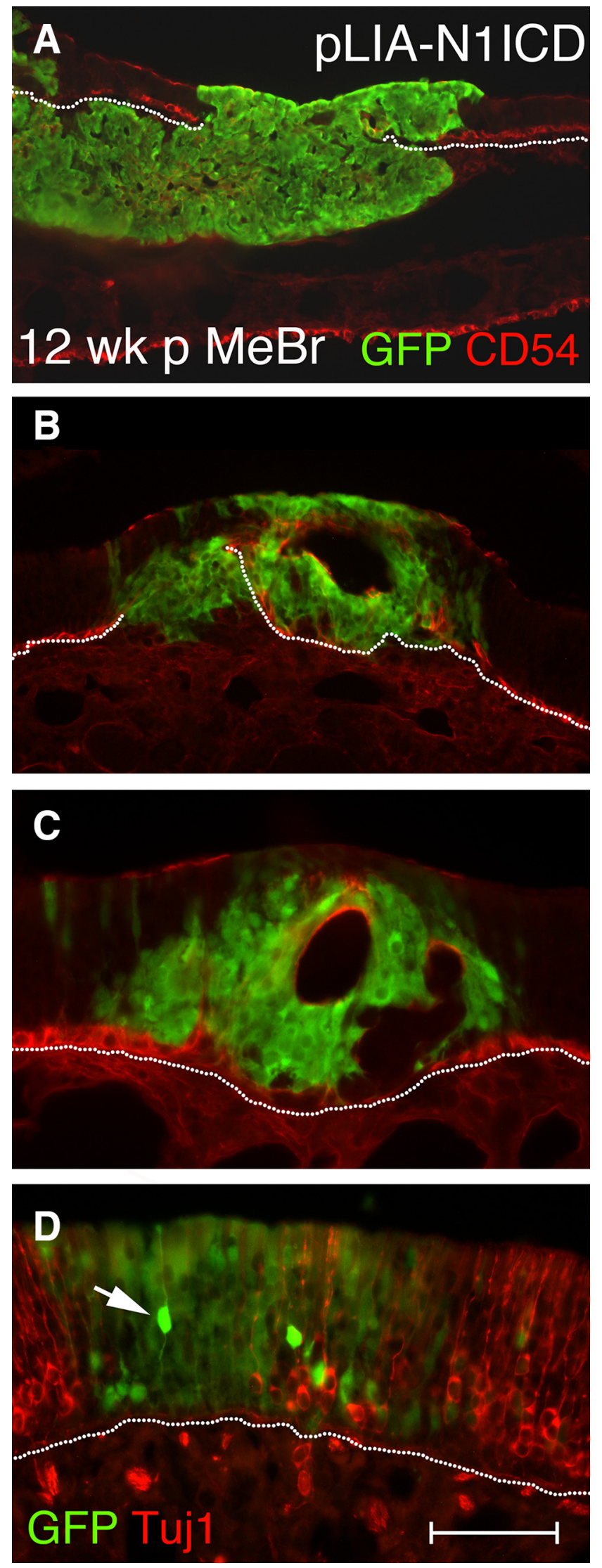

Figure 9. Long-term retroviral transduction-mediated N1ICD overexpression also leads to the formation of tumors in rats. $\boldsymbol{A}-\boldsymbol{D}$, Long-term overexpression of N1ICD by retroviral infection in the rat $0 \mathrm{E}$ has a similar phenotype to that observed when $N 1$ ICD is constitutively expressed following genetic recombination in mice. $D, 0$ n occasion, GFP-labeled neurons are seen, which been disrupted or depleted altogether as a consequence, as seen by scant p63 staining (Fig. 8E-E2).

Transduction of lesioned rat OE with the pLIA-N1ICD retrovirus had comparable long-term effects on the structure of the epithelium (Fig. 9A-C). As in the transgenic mice, a mass of labeled cells breached the basal lamina and invaded the lamina propria (Fig. 9A,B) and/or distorted epithelial structure by forming cysts and interrupting the CD54-stained HBC monolayer (Fig. 9C). In other clones, the transduced cells remained aberrant and interrupted the neuronal layer, but confined to the epithelium. Rare neurons were also seen, suggesting that N1ICD expression may have been silenced several weeks postinfection (Fig. 9D)

\section{Discussion}

The present results suggest that canonical Notch signaling drives the differentiation of non-neuronal cells during the reconstitution of the $\mathrm{OE}$ after MeBr-induced epithelial injury. Three lines of evidence support that conclusion: (1) the formation of both Suslike cells and duct/gland-like cells following transduction of spared GBCs and duct/gland cells with N1ICD, and of Sus-like cells following conditional expression of N1ICD by HBCs; (2) the diversion of the HBC progeny toward the formation of neurons when both Notch 1 and Notch 2 are eliminated by conditional recombination; and 3) the diversion toward neurons when canonical Notch signaling is blocked by either transduction of GBCs and duct/gland cells with the dominant-negative form of MAML, a necessary cofactor of canonical Notch signaling, or by excision of the DNA binding domain of RBPJ in HBCs (Artavanis-Tsakonas and Muskavitch, 2010).

Several other subsidiary points emerge. First, the blocking of non-neuronal differentiation and a diversion to a neuronal fate does not occur until both Notch1 and Notch2 receptors are excised. Thus, the commitment to a non-neuronal fate is neither Notch receptor dose- nor type-dependent, but rather appears to be an all-or-none phenomenon that requires some level of signaling even if that level is less than the full gene dosage. Second, the N1ICD-induced commitment to a non-neuronal fate is dependent on the status of the canonical Notch cofactor RBPJ, since a shift back toward neuronal differentiation is observed in animals that are either homozygous or heterozygous for the floxed DNA-binding domain allele of RBPJ. Third, after HBC-derived Sus cell form, we find that Notch2, but not Notch1, is required for their survival, which is also true of Sus cells in the developing OE (Rodriguez et al., 2008). Our demonstration that Notch2 knockout leads to activation of Caspase 3 and the death of Sus cell progeny replicates and extends the previous demonstration using a different driver, different age, and a different cellular locus for recombination and excision (Rodriguez et al., 2008).

\section{Notch signaling and the specification of cell fate}

That Notch signaling drives the differentiation of non-neuronal cell types during the reconstitution of the olfactory epithelium raises additional considerations. Among them are the contextual influences on Notch signaling in HBCs, the signaling events driving lineage determination, and the sequencing of events during epithelial reconstitution. First, the influence of context on Notch

may reflect silencing of $N 1 I C D$ or insertion of the retroviral genome in the vicinity and under the partial control of a gene encoding an olfactory receptor (Zhuo et al., 2001). The latter is suggested by the greater intensity of staining in the neuronal cells. Scale bar, $50 \mu \mathrm{m}$. 
signaling is apparent from the consequences of Notch1 deletion in the absence of direct epithelial injury (Herrick et al., 2017). The excision of both alleles of Notch 1 results in a significant but low rate of $\mathrm{HBC}$ activation in the setting of an undamaged OE in which neuronal turnover is piecemeal, and markedly enhanced activation following ablation of the olfactory bulb, which causes wholesale retrograde neuronal degeneration and secondarily upregulates GBC proliferation and neurogenesis (Herrick et al., 2017). Because HBC activation is also observed after selective Sus cell death, the normal expression of Jag 1 by Sus cells may be the ligand responsible for activating Notch signaling and maintaining $\mathrm{HBC}$ dormancy in the absence of injury or following bulb ablation (Herrick et al., 2017). However, because RBPJ mutation does not result in HBC activation, it is unlikely that the Notch signaling that contributes to the maintenance of dormancy is mediated via the canonical pathway (Herrick et al., 2017). It is worth noting that the drive to $\mathrm{HBC}$ activation after severe and direct epithelial injury apparently supersedes the influence of Notch signaling in restraining activation, because the number of HBCs observed after $\mathrm{MeBr}$ injury is comparable to wild-type when N1ICD expression is driven by genetic manipulation in mice (Herrick et al., 2017).

Second, although canonical Notch signaling is necessary and sufficient for the progeny of HBCs to adopt a non-neuronal fate, the identity and location of the corresponding ligand is undetermined. Notably, HBCs express Delta-like1, along with a lesser level of Jag1 expression (Herrick et al., 2017). Ligand expression by HBCs raises the possibility of either cis- or trans-signaling, or both, although cis-signaling is usually inhibitory in nature (del Álamo et al., 2011).

Third, activated HBCs must transition into GBCs, to replace the neuronal population during epithelial reconstitution (Jang et al., 2003). On the other hand, the question of whether activated HBCs can differentiate directly into Sus cells cannot be answered definitively. That HBCs bridge the height of the regenerating OE to contact the epithelial surface and begin to differentiate into Sus cells suggest that they may (Schwob et al., 1995). Furthermore, pseudo-time inference based on Slingshot analysis of RNAseq data also suggests that newly activated HBCs transition directly to Sus cells when p63 is conditionally excised or after epithelial injury (Fletcher et al., 2017; Gadye et al., 2017). Nonetheless, GBCs also act as a nexus for lineage determination in response to Notch signaling because (1) Sus-like cells are formed following N1ICD transduction of presumed GBCs in rat, (2) the GBC progeny divert uniformly to neurons after dnMAML transduction, and (3) Sus-only clones arise following GBC transplantation into the lesioned OE of both rats and mice (Goldstein et al., 1998; Chen et al., 2004; Schnittke et al., 2015).

\section{Notch 1 and Notch 2 are redundant and not dose-dependent in determining progenitor lineage}

That HBC-conditional deletion of Notch1 while sparing Notch2, and vice-versa, do not apparently alter HBC-derived progeny following $\mathrm{MeBr}$ lesion suggests that any degree of Notch signaling is sufficient to drive lineage determination and is unaffected by gene dose. That Notch1 and Notch 2 are functionally redundant for cell fate determination is not unknown. For example, Notch1 and Notch2 exhibit functional redundancy when regulating leftright asymmetry via the Nodal gene in the developing mouse (Krebs et al., 2003). Conversely, Notch1 and Notch2 are known to have distinct, i.e., non-redundant, roles in some tissues. For example, both Notch 1 and Notch 2 are expressed in the early renal vesicle, but only Notch2 is required for differentiation of the proximal nephron structures despite activation of Notch1 and translocation to the nucleus (Cheng et al., 2007).

\section{RBPJ haploinsufficiency abrogates the effect of N1ICD overexpression on non-neuronal lineage commitment}

The finding that excision of the DNA binding domain of a single RBPJ allele was sufficient to obstruct the effect of N1ICD expression is surprising and suggests that RBPJ is haploinsufficient. It is conceivable that the outcome is a dominant-negative or a neomorphic effect of the mutant RBPJ. However, neither mRNA nor protein is detectable in other tissues following recombination at both alleles, which tends to eliminate the dominant-negative and neomorphic genetic explanations (lymphocytes: Tanigaki et al., 2002; inner ear: Basch et al., 2011). The finding of RBPJ haploinsufficiency is relatively novel. Descriptions of mice that bear the same heterozygous genotype as we bred here are limited and have not revealed a phenotype compared with wild-type mice (Raafat et al., 2009) There is one exception. Heterozygous mice display an enhanced propensity for diet-induced aortic valve disease (Nus et al., 2011). RBPJ:N1ICD stoichiometry is potentially a determining factor in cell behavior, as Notch signaling is one of few pathways that lacks an enzymatic amplification step and is more dependent on gene dosage (Artavanis-Tsakonas and Muskavitch, 2010; Southgate et al., 2015). Consistent with the foregoing interpretation, other Notch signaling components do evidence a potential for haploinsufficiency. For example, phenotypic abnormalities in humans and mice are associated with a single mutant allele at the Jag1 (Alagille syndrome; Krebs et al., 2004) and Dll4 loci (Mašek and Andersson, 2017); RBPJ mutation in humans is a variably penetrant autosomal dominant condition as well (Mašek and Andersson, 2017).

\section{Prolonged exogenous Notch1-ICD expression leads to increased cell proliferation and aberrant cellular growth} The overexpression of N1ICD in HBCs after injury caused sustained proliferation of the Sus-like and duct/gland-like cells beyond the period when they would normally be dividing in the regenerating OE (Schwob et al., 1995). The formation of aberrant cell masses that invade the lamina propria is reminiscent of the pathology observed with olfactory neuroblastomas (Holbrook et al., 2011). The study of Notch signaling in such tumors may be a fruitful avenue for investigation in the future.

\section{Conclusion}

In summary, these data show that canonical Notch signaling determines neuronal versus non-neuronal fate in the regenerating olfactory epithelium. Our findings here and previously (Herrick et al., 2017) align well with observations in other parts of the nervous system. For example, Notch promotes the acquisition of glial identity by astrocytes, radial glia in the forebrain and cerebellum, Müller glia in the retina, and Schwann cells (for review, see Gaiano and Fishell, 2002). Notch signaling also maintains neural stem cells in the developing and adult CNS as shown by their premature differentiation following conditional RBPJ knock-out (Imayoshi et al., 2010), which may be analogous to the effect of Notch1 signaling on HBC dormancy (Herrick et al., 2017). Importantly, we suggest that fate is independent of Notch receptor dose. Nonetheless, both alleles of RBPJ are required for N1ICD to efficiently drive non-neuronal differentiation. Notch also behaves as an oncogene in the Sus-like and duct/gland-like cells, increasing rates of cell division and enabling cells to invade adjacent tissues. 


\section{References}

Artavanis-Tsakonas S, Muskavitch MA (2010) Notch: the past, the present, and the future. Curr Top Dev Biol 92:1-29. CrossRef Medline

Badea TC, Hua ZL, Smallwood PM, Williams J, Rotolo T, Ye X, Nathans J (2009) New mouse lines for the analysis of neuronal morphology using CreER(T)/loxP-directed sparse labeling. PLoS One 4:e7859. CrossRef Medline

Basch ML, Ohyama T, Segil N, Groves AK (2011) Canonical notch signaling is not necessary for prosensory induction in the mouse cochlea: insights from a conditional mutant of $R B P_{\mathrm{j} \kappa}$. J Neurosci 31:8046-8058. CrossRef Medline

Caggiano M, Kauer JS, Hunter DD (1994) Globose basal cells are neuronal progenitors in the olfactory epithelium: a lineage analysis using a replicationincompetent retrovirus. Neuron 13:339-352. CrossRef Medline

Carson C, Murdoch B, Roskams AJ (2006) Notch 2 and notch 1/3 segregate to neuronal and glial lineages of the developing olfactory epithelium. Dev Dyn 235:1678-1688. CrossRef Medline

Cau E, Casarosa S, Guillemot F (2002) Mash1 and Ngn1 control distinct steps of determination and differentiation in the olfactory sensory neuron lineage. Development 129:1871-1880. Medline

Chen X, Fang H, Schwob JE (2004) Multipotency of purified, transplanted globose basal cells in olfactory epithelium. J Comp Neurol 469:457-474. CrossRef Medline

Cheng HT, Kim M, Valerius MT, Surendran K, Schuster-Gossler K, Gossler A, McMahon AP, Kopan R (2007) Notch2, but not Notch1, is required for proximal fate acquisition in the mammalian nephron. Development 134:801-811. CrossRef Medline

Dang L, Yoon K, Wang M, Gaiano N (2006) Notch3 signaling promotes radial glial/progenitor character in the mammalian telencephalon. Dev Neurosci 28:58-69. CrossRef Medline

de La Coste A, Six E, Fazilleau N, Mascarell L, Legrand N, Mailhé MP, Cumano A, Laâbi Y, Freitas AA (2005) In vivo and in absence of a thymus, the enforced expression of the notch ligands delta-1 or delta-4 promotes T cell development with specific unique effects. J Immunol 174: 2730-2737. CrossRef Medline

del Álamo D, Rouault H, Schweisguth F (2011) Mechanism and significance of cis-inhibition in notch signaling. Curr Biol 21:R40-R47. CrossRef Medline

Doetsch F, Caillé I, Lim DA, García-Verdugo JM, Alvarez-Buylla A (1999) Subventricular zone astrocytes are neural stem cells in the adult mammalian brain. Cell 97:703-716. CrossRef Medline

Ellisen LW, Bird J, West DC, Soreng AL, Reynolds TC, Smith SD, Sklar J (1991) TAN-1, the human homolog of the Drosophila Notch gene, is broken by chromosomal translocations in T lymphoblastic neoplasms. Cell 66:649-661. CrossRef Medline

Fletcher RB, Prasol MS, Estrada J, Baudhuin A, Vranizan K, Choi YG, Ngai J (2011) p63 regulates olfactory stem cell self-renewal and differentiation. Neuron 72:748-759. CrossRef Medline

Fletcher RB, Das D, Gadye L, Street KN, Baudhuin A, Wagner A, Cole MB, Flores Q, Choi YG, Yosef N, Purdom E, Dudoit S, Risso D, Ngai J (2017) Deconstructing olfactory stem cell trajectories at single-cell resolution. Cell Stem Cell 20:817-830. Medline

Gadye L, Das D, Sanchez MA, Street K, Baudhuin A, Wagner A, Cole MB, Choi YG, Yosef N, Purdom E, Dudoit S, Risso D, Ngai J, Fletcher RB (2017) Injury activates transient olfactory stem cell states with diverse lineage capacities. Cell Stem Cell 21:775-790. CrossRef Medline

Gaiano N, Fishell G (2002) The role of notch in promoting glial and neural stem cell fates. Annu Rev Neurosci 25:471-490. CrossRef Medline

Goldstein BJ, Schwob JE (1996) Analysis of the globose basal cell compartment in rat olfactory epithelium using GBC-1, a new monoclonal antibody against globose basal cells. J Neurosci 16:4005-4016. CrossRef Medline

Goldstein BJ, Fang H, Youngentob SL, Schwob JE (1998) Transplantation of multipotent progenitors from the adult olfactory epithelium. Neuroreport 9:1611-1617. CrossRef Medline

Graziadei PP, Monti Graziadei GA (1979) Neurogenesis and neuron regeneration in the olfactory system of mammals: I. morphological aspects of differentiation and structural organization of the olfactory sensory neurons. J Neurocytol 8:1-18. CrossRef Medline

Guo Z, Packard A, Krolewski RC, Harris MT, Manglapus GL, Schwob JE (2010) Expression of pax6 and sox 2 in adult olfactory epithelium. J Comp Neurol 518:4395-4418. CrossRef Medline
Han H, Tanigaki K, Yamamoto N, Kuroda K, Yoshimoto M, Nakahata T, Ikuta K, Honjo T (2002) Inducible gene knock-out of transcription factor recombination signal binding protein-J reveals its essential role in $\mathrm{T}$ versus B lineage decision. Int Immunol 14:637-645. CrossRef Medline

Herrick DB, Lin B, Peterson J, Schnittke N, Schwob JE (2017) Notch1 maintains dormancy of olfactory horizontal basal cells, a reserve neural stem cell. Proc Natl Acad Sci USA. 114:E5589-E5598. CrossRef Medline

Holbrook EH, Szumowski KE, Schwob JE (1995) An immunochemical, ultrastructural, and developmental characterization of the horizontal basal cells of rat olfactory epithelium. J Comp Neurol 363:129-146. CrossRef Medline

Holbrook EH, Wu E, Curry WT, Lin DT, Schwob JE (2011) Immunohistochemical characterization of human olfactory tissue. Laryngoscope 121: 1687-1701. CrossRef Medline

Holbrook EH, Iwema CL, Peluso CE, Schwob JE (2014) The regeneration of P2 olfactory sensory neurons is selectively impaired following methyl bromide lesion. Chem Senses 39:601-616. CrossRef Medline

Hozumi K, Abe N, Chiba S, Hirai H, Habu S (2003) Active form of notch members can enforce $\mathrm{T}$ lymphopoiesis on lymphoid progenitors in the monolayer culture specific for B cell development. J Immunol 170:49734979. CrossRef Medline

Huard JM, Youngentob SL, Goldstein BJ, Luskin MB, Schwob JE (1998) Adult olfactory epithelium contains multipotent progenitors that give rise to neurons and non-neural cells. J Comp Neurol 400:469-486. CrossRef Medline

Imayoshi I, Sakamoto M, Yamaguchi M, Mori K, Kageyama R (2010) Essential roles of notch signaling in maintenance of neural stem cells in developing and adult brains. J Neurosci 30:3489-3498. CrossRef Medline

Indra AK, Warot X, Brocard J, Bornert JM, Xiao JH, Chambon P, Metzger D (1999) Temporally-controlled site-specific mutagenesis in the basal layer of the epidermis: comparison of the recombinase activity of the tamoxifen-inducible cre-ER ${ }^{\mathrm{T}}$ and cre-ER ${ }^{\mathrm{T} 2}$ recombinases. Nucleic Acids Res 27:4324-4327. CrossRef Medline

Ishibashi M, Moriyoshi K, Sasai Y, Shiota K, Nakanishi S, Kageyama R (1994) Persistent expression of helix-loop-helix factor HES-1 prevents mammalian neural differentiation in the central nervous system. EMBO J 13: 1799-1805. Medline

Iwai N, Zhou Z, Roop DR, Behringer RR (2008) Horizontal basal cells are multipotent progenitors in normal and injured adult olfactory epithelium. Stem Cells 26:1298-1306. CrossRef Medline

Iwema CL, Fang H, Kurtz D, Youngentob SL, Schwob JE (2004) Odorant receptor expression patterns are restored in lesioned-recovered rat olfactory epithelium. J. Neurosci., 24:356-369. CrossRef Medline

Jang W, Youngentob SL, Schwob JE (2003) Globose basal cells are required for reconstitution of olfactory epithelium after methyl bromide lesion. J Comp Neurol 460:123-140. CrossRef Medline

Jang W, Lambropoulos J, Woo JK, Peluso CE, Schwob JE (2008) Maintaining epitheliopoietic potency when culturing olfactory progenitors. Exp Neurol 214:25-36. CrossRef Medline

Kopan R, Ilagan MX (2009) The canonical notch signaling pathway: unfolding the activation mechanism. Cell 137:216-233. CrossRef Medline

Krebs LT, Iwai N, Nonaka S, Welsh IC, Lan Y, Jiang R, Saijoh Y, O’Brien TP, Hamada H, Gridley T (2003) Notch signaling regulates left-right asymmetry determination by inducing nodal expression. Genes Dev 17:12071212. CrossRef Medline

Krebs LT, Shutter JR, Tanigaki K, Honjo T, Stark KL, Gridley T (2004) Haploinsufficient lethality and formation of arteriovenous malformations in notch pathway mutants. Genes Dev 18:2469-2473. CrossRef Medline

Krolewski RC, Packard A, Jang W, Wildner H, Schwob JE (2012) Ascll (Mash1) knockout perturbs differentiation of nonneuronal cells in olfactory epithelium. PLoS One. 7:e51737. CrossRef Medline

Krolewski RC, Packard A, Schwob JE (2013) Global expression profiling of globose basal cells and neurogenic progression within the olfactory epithelium. J Comp Neurol 521:833-859. CrossRef Medline

Kumano K, Chiba S, Kunisato A, Sata M, Saito T, Nakagami-Yamaguchi E, Yamaguchi T, Masuda S, Shimizu K, Takahashi T, Ogawa S, Hamada Y, Hirai H (2003) Notch1 but not Notch2 is essential for generating hematopoietic stem cells from endothelial cells. Immunity 18:699-711. CrossRef Medline

Leung CT, Coulombe PA, Reed RR (2007) Contribution of olfactory neural stem cells to tissue maintenance and regeneration. Nat Neurosci 10:720726. CrossRef Medline 
Lin B, Coleman JH, Peterson JN, Zunitch MJ, Jang W, Herrick DB, Schwob JE (2017) Injury induces endogenous reprogramming and dedifferentiation of neuronal progenitors to multipotency. Cell Stem Cell 21:761-774. CrossRef

Long MA, Rossi FM (2009) Silencing inhibits cre-mediated recombination of the Z/AP and Z/EG reporters in adult cells. PLoS One 4:e5435. CrossRef Medline

Madisen L, Zwingman TA, Sunkin SM, Oh SW, Zariwala HA, Gu H, Ng LL, Palmiter RD, Hawrylycz MJ, Jones AR, Lein ES, Zeng H (2010) A robust and high-throughput cre reporting and characterization system for the whole mouse brain. Nat Neurosci 13:133-140. CrossRef Medline

Maier E, Nord H, von Hofsten J, Gunhaga L (2011) A balance of BMP and notch activity regulates neurogenesis and olfactory nerve formation. PLoS One 6:e17379. CrossRef Medline

Maillard I, Weng AP, Carpenter AC, Rodriguez CG, Sai H, Xu L, Allman D, Aster JC, Pear WS (2004) Mastermind critically regulates notchmediated lymphoid cell fate decisions. Blood 104:1696-1702. CrossRef Medline

Manglapus GL, Youngentob SL, Schwob JE (2004) Expression patterns of basic helix-loop-helix transcription factors define subsets of olfactory progenitor cells. J Comp Neurol 479:216-233. CrossRef Medline

Mašek J, Andersson ER (2017) The developmental biology of genetic notch disorders. Development 144:1743-1763. CrossRef Medline

McCright B, Lozier J, Gridley T (2006) Generation of new Notch2 mutant alleles. Genesis 44:29-33. CrossRef Medline

Mercher T, Cornejo MG, Sears C, Kindler T, Moore SA, Maillard I, Pear WS, Aster JC, Gilliland DG (2008) Notch signaling specifies megakaryocyte development from hematopoietic stem cells. Cell Stem Cell 3:314-326. CrossRef Medline

Monti Graziadei GA, Monti Graziadei PP (1979) Neurogenesis and neuron regeneration in the olfactory system of mammals: II. Degeneration and reconstitution of the olfactory sensory neurons after axotomy. J Neurocytol 8:197-213. CrossRef Medline

Murtaugh LC, Stanger BZ, Kwan KM, Melton DA (2003) Notch signaling controls multiple steps of pancreatic differentiation. Proc Natl Acad Sci U S A 100:14920-14925. CrossRef Medline

Nicolas M, Wolfer A, Raj K, Kummer JA, Mill P, van Noort M, Hui CC, Clevers H, Dotto GP, Radtke F (2003) Notch1 functions as a tumor suppressor in mouse skin. Nat Genet 33:416-421. CrossRef Medline

Nus M, MacGrogan D, Martínez-Poveda B, Benito Y, Casanova JC, Fernández-Avilés F, Bermejo J, de la Pompa JL (2011) Diet-induced aortic valve disease in mice haploinsufficient for the notch pathway effector RBPJK/CSL. Arterioscler Thromb Vasc Biol 31:1580-1588. CrossRef Medline

Packard A, Giel-Moloney M, Leiter A, Schwob JE (2011) The progenitor cell capacity of NeuroD1-expressing globose basal cells in the mouse olfactory epithelium. J Comp Neurol 519:3580-3596. CrossRef Medline

Pear WS, Aster JC, Scott ML, Hasserjian RP, Soffer B, Sklar J, Baltimore D (1996) Exclusive development of T cell neoplasms in mice transplanted with bone marrow expressing activated notch alleles. J Exp Med 183: 2283-2291. CrossRef Medline

Pham L, Ye H, Cosset FL, Russell SJ, Peng KW (2001) Concentration of viral vectors by co-precipitation with calcium phosphate. J Gene Med 3:188194. CrossRef Medline

Raafat A, Lawson S, Bargo S, Klauzinska M, Strizzi L, Goldhar AS, Buono K, Salomon D, Vonderhaar BK, Callahan R (2009) Rbpj conditional knockout reveals distinct functions of Notch4/Int3 in mammary gland development and tumorigenesis. Oncogene 28:219-230. CrossRef Medline

Radtke F, Raj K (2003) The role of notch in tumorigenesis: oncogene or tumour suppressor? Nat Rev Cancer 3:756-767. CrossRef Medline

Riccio O, van Gijn ME, Bezdek AC, Pellegrinet L, van Es JH, Zimber-Strobl U, Strobl LJ, Honjo T, Clevers H, Radtke F (2008) Loss of intestinal crypt progenitor cells owing to inactivation of both Notch1 and Notch2 is accompanied by derepression of CDK inhibitors p27Kip1 and p57Kip2. EMBO Rep 9:377-383. CrossRef Medline

Rodriguez S, Sickles HM, DeLeonardis C, Alcaraz A, Gridley T, Lin DM (2008) Notch2 is required for maintaining sustentacular cell function in the adult mouse main olfactory epithelium. Dev Biol 314:40 -58. CrossRef Medline

Sakamoto M, Hirata H, Ohtsuka T, Bessho Y, Kageyama R (2003) The basic helix-loop-helix genes Hesr1/Hey1 and Hesr2/Hey2 regulate maintenance of neural precursor cells in the brain. J Biol Chem 278:44808-44815. CrossRef Medline

Schnittke N, Herrick DB, Lin B, Peterson J, Coleman JH, Packard AI, Jang W, Schwob JE (2015) Transcription factor p63 controls the reserve status but not the stemness of horizontal basal cells in the olfactory epithelium. Proc Natl Acad Sci U S A 112:E5068-E5077. CrossRef Medline

Schwarting GA, Gridley T, Henion TR (2007) Notch1 expression and ligand interactions in progenitor cells of the mouse olfactory epithelium. J Mol Histol 38:543-553. CrossRef Medline

Schwob JE (2002) Neural regeneration and the peripheral olfactory system. Anat Rec 269:33-49. CrossRef Medline

Schwob JE, Huard JM, Luskin MB, Youngentob SL (1994) Retroviral lineage studies of the rat olfactory epithelium. Chem Senses 19:671-682. CrossRef Medline

Schwob JE, Youngentob SL, Mezza RC (1995) Reconstitution of the rat olfactory epithelium after methyl bromide-induced lesion. J Comp Neurol 359:15-37. CrossRef Medline

Schwob JE, Jang W, Holbrook EH, Lin B, Herrick DB, Peterson JN, Hewitt Coleman JH (2017) The stem and progenitor cells of the mammalian olfactory epithelium: taking poietic license. J Comp Neurol 525:10341054. CrossRef Medline

Southgate L Sukalo M, Karountzos ASV, Taylor EJ, Collinson CS, Ruddy D, Snape KM, Dallapiccola B, Tolmie JL, Joss S, Brancati F, Digilio MC, Graul-Neumann LM, Salviati L, Coerdt W, Jacquemin E, Wuyts W, Zenker M, Machado RD, Trembath RC (2015) Haploinsufficiency of the NOTCH1 receptor as a cause of Adams-Oliver syndrome with variable cardiac anomalies. Circ Cardiovasc Genet 8:572-581. CrossRef Medline

Talora C, Sgroi DC, Crum CP, Dotto GP (2002) Specific down-modulation of Notch1 signaling in cervical cancer cells is required for sustained HPVE6/E7 expression and late steps of malignant transformation. Genes Dev 16:2252-2263. CrossRef Medline

Tanigaki K, Han H, Yamamoto N, Tashiro K, Ikegawa M, Kuroda K, Suzuki A, Nakano T, Honjo T (2002) Notch-RBP-J signaling is involved in cell fate determination of marginal zone B cells. Nat Immunol 3:443-450. CrossRef Medline

van Es JH, van Gijn ME, Riccio O, van den Born M, Vooijs M, Begthel $\mathrm{H}$, Cozijnsen M, Robine S, Winton DJ, Radtke F, Clevers H (2005) Notch/ $\gamma$-secretase inhibition turns proliferative cells in intestinal crypts and adenomas into goblet cells. Nature 435:959-963. CrossRef Medline

Weijzen S, Rizzo P, Braid M, Vaishnav R, Jonkheer SM, Zlobin A, Osborne BA, Gottipati S, Aster JC, Hahn WC, Rudolf M, Siziopikou K, Kast WM, Miele L (2002) Activation of notch-1 signaling maintains the neoplastic phenotype in human ras-transformed cells. Nat Med 8:979-986. CrossRef Medline

Yang X, Klein R, Tian X, Cheng HT, Kopan R, Shen J (2004) Notch activation induces apoptosis in neural progenitor cells through a p53dependent pathway. Dev Biol 269:81-94. CrossRef Medline

Zagouras P, Stifani S, Blaumueller CM, Carcangiu ML, Artavanis-Tsakonas S (1995) Alterations in notch signaling in neoplastic lesions of the human cervix. Proc Natl Acad Sci U S A 92:6414-6418. CrossRef Medline

Zhuo X, Schwob JE, Swiatek PJ, Ding X (2001) Mouse Cyp2G1 gene: promoter structure and tissue-specific expression of a Cyp2G1-LacZ fusion gene in transgenic mice. Arch Biochem Biophys 391:127-136. CrossRef Medline 